\title{
Handbook for Handling, Storing, and Dispensing E85 and Other Ethanol-Gasoline Blends
}

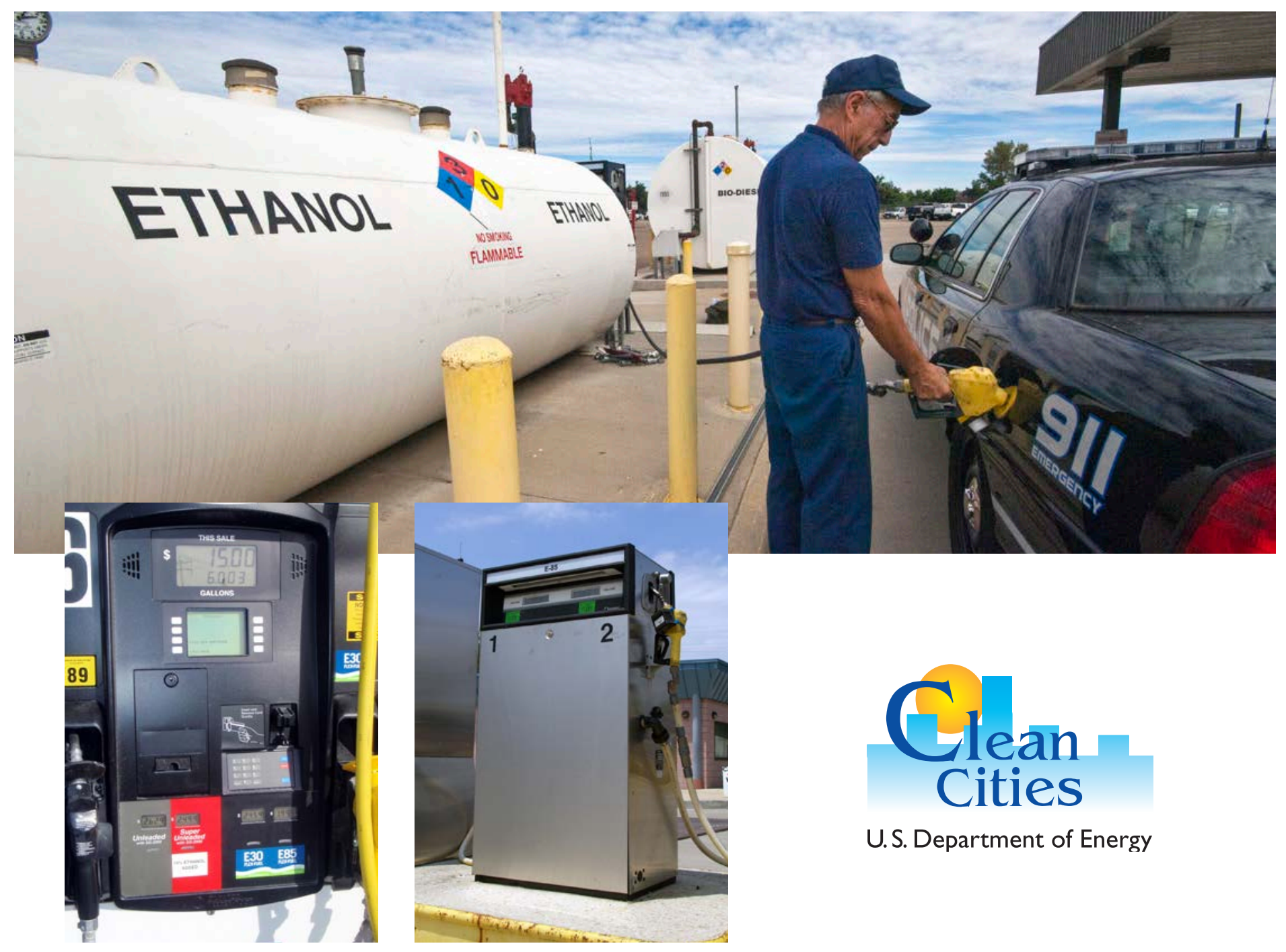

DOE/GO-102013-3861

September 2013 


\section{Disclaimer}

This report was prepared as an account of work sponsored by an agency of the United States government. Neither the United States government nor any agency thereof, nor any of their employees, makes any warranty, express or implied, or assumes any legal liability or responsibility for the accuracy, completeness, or usefulness of any information, apparatus, product, or process disclosed, or represents that its use would not infringe privately owned rights. Reference herein to any specific commercial product, process, or service by trade name, trademark, manufacturer, or otherwise does not necessarily constitute or imply its endorsement, recommendation, or favoring by the United States government or any agency thereof. The views and opinions of authors expressed herein do not necessarily state or reflect those of the United States government or any agency thereof.

Every effort has been made to ensure that this manual is accurate, complete, and comprehensive at the time of publication. It is intended to be used as a guide and resource document. The authors strongly encourage all parties with an interest in establishing E85 or other ethanol blends fueling systems to engage professional support during installation to ensure fuel integrity and systems compatibility.

This document is not intended for use as a "how to" guide for individuals or organizations performing conversions. 


\section{Contents}

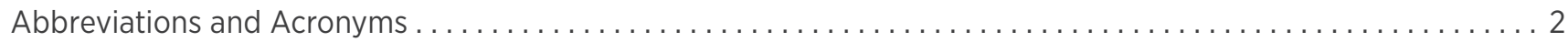

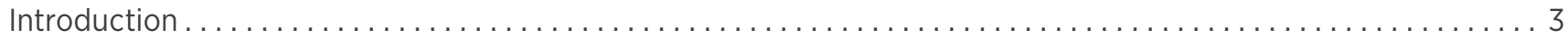

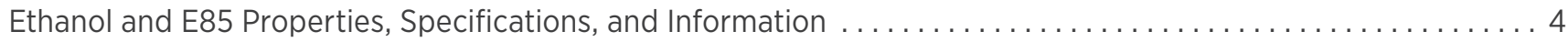

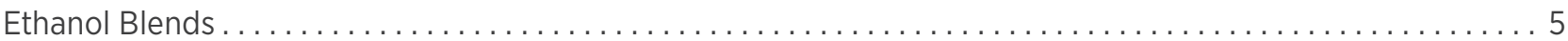

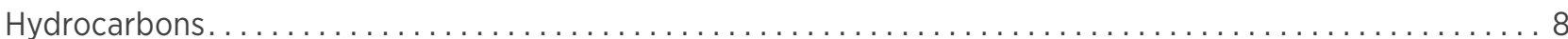

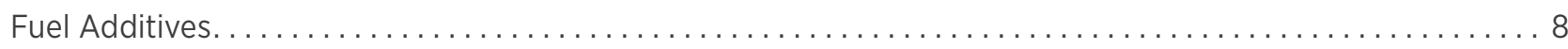

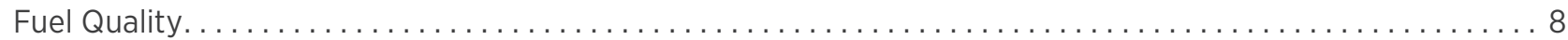

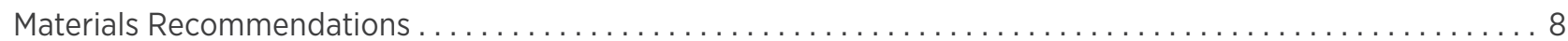

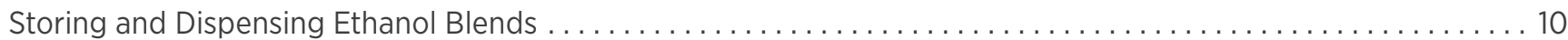

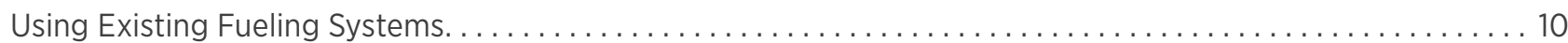

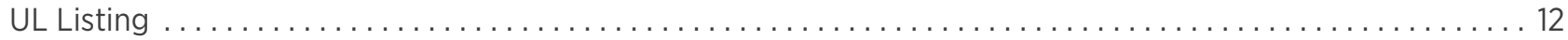

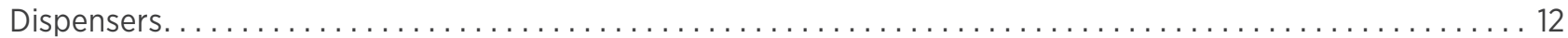

Hanging Hardware. . . . . . . . . . . . . . . . . . . . . . . . 13

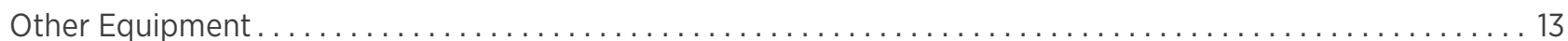

Signs and Labels . . . . . . . . . . . . . . . . . . . . . . . . . . . . . . . . . . . . . . . . . . . . . . . . . . . . . . . 15

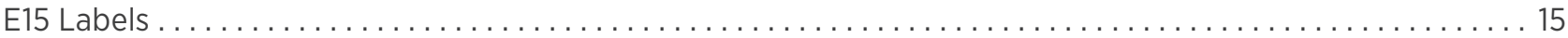

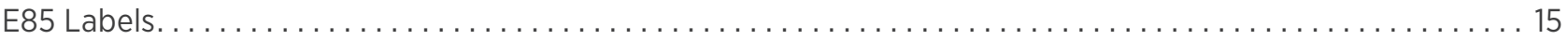

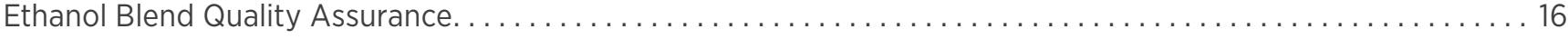

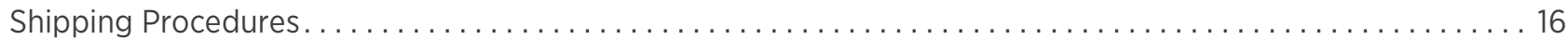

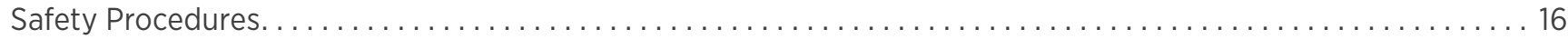

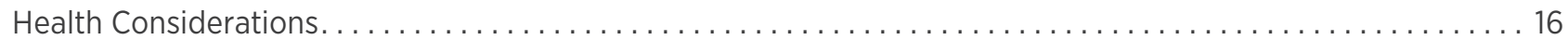

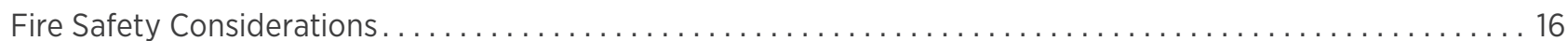

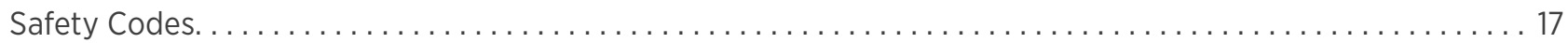

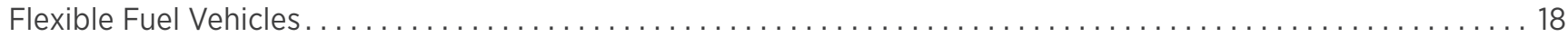

Checklist for Installing E85 or Blender Pump Dispensing Equipment or

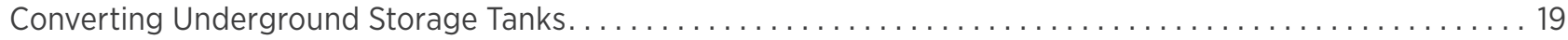

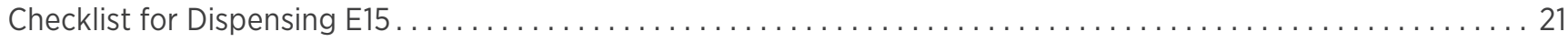

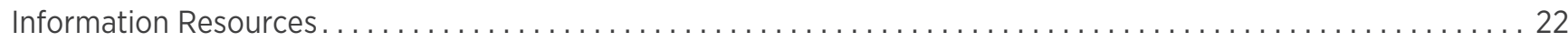

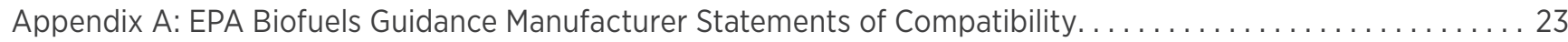

Appendix B: Various Specifications for Fuel Ethanol, E85, and Denaturant $\ldots \ldots \ldots \ldots \ldots \ldots \ldots \ldots \ldots \ldots .28$

Appendix C: Seasonal and Geographical Volatility Classes for E85 (ASTM D5798) . . . . . . . . . . . . . . 31

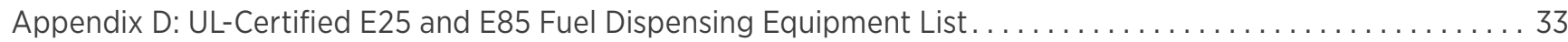

Appendix E: Procedures for Determining Selected Properties of Ethanol Fuel Samples . . . . . . . . . . . . . . . 36

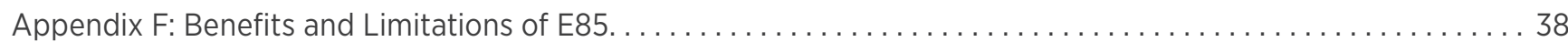




\section{Abbreviations and Acronyms}

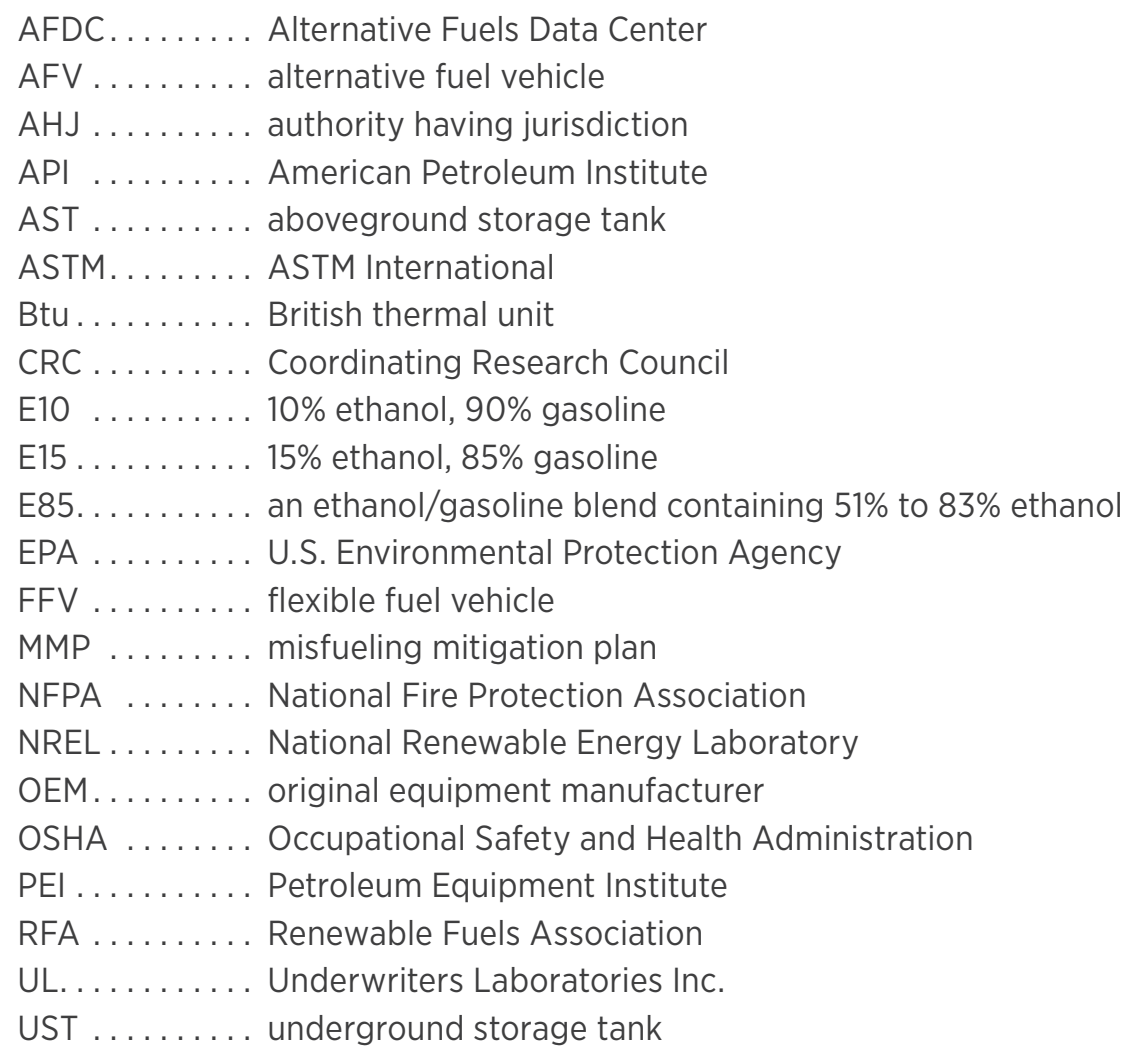




\section{Introduction}

This document serves as a guide for blenders, distributors, sellers, and users of E85 and other ethanol blends above E10. It provides basic information on the proper and safe use of E85 and other ethanol blends and includes supporting technical and policy references.

Ethanol is a renewable, domestically produced fuel that can be made from grains, such as corn or wheat, or from cellulose sources, such as prairie grass or agricultural, forestry, or municipal wastes. Several research studies show that ethanol/gasoline blends, and E85 specifically, have the potential to substantially reduce petroleum fuel use and greenhouse gas emissions. ${ }^{1}$

E85 is an alternative motor fuel authorized by the Energy Policy Act of 1992, Section 301(2). In 2011, the U.S. Environmental Protection Agency (EPA) approved the use of E15 in conventional light-duty vehicles of model year 2001 and newer. E85, E15, and all mid-level blends between the two require special considerations related to storage, dispensing, handling, and vehicle operation, as compared to gasoline.

Driven by fluctuating gasoline prices and the Renewable Fuel Standard, the market for E85 and other ethanol blends is growing. In response, auto manufacturers are continuing to produce more flexible fuel vehicles (FFVs), which are capable of operating on E85 or gasoline or any blend of the two. According to the U.S. Department of Energy's Energy Information Administration, there were 10.7 million FFVs in use in 2012. FFVs are available in most vehicle classes, including sedans, minivans, trucks, and sport utility vehicles. The number of E85 fueling stations is also growing. As of August 2013, more than 2,300 retail stations across the country offered E85. More than 340 of these stations had blender pumps, which offer mid-level ethanol blends, such as E20 and E30.

Underwriters Laboratories Inc. (UL) has established standardized testing procedures for E10, E25, and E85 infrastructure. All fueling equipment manufacturers offer equipment that is UL listed for E10; many manufacturers offer equipment that is UL listed for use with blends up to E25 and/or equipment listed for use with blends up to E85. Stations dispensing E15 should use equipment listed for blends up to E25 or up to E85. EPA's Office of Underground Storage Tanks has developed guidance to inform station owners on how to meet federal code while storing E85. See Appendices A and D for detailed information.

There are several federal and state tax incentives to encourage the installation of E85 infrastructure and blender pumps. For a comprehensive list of these programs, visit the Federal and State Laws and Incentives section of the Alternative Fuels Data Center (AFDC) at afdc.energy.gov/laws.

\section{A Note on Terminology: Flex Fuel and E85}

"E85" is thought by many to denote a vehicle fuel containing $85 \%$ ethanol and $15 \%$ gasoline. However, the ethanol portion of the blend must contain, by law, at least $2 \%$ denaturant (a hydrocarbon or hydrocarbons in the gasoline boiling range). Therefore, E85 actually contains $83 \%$ ethanol at most. Furthermore, in cold weather conditions, a greater percentage of gasoline is required in the blend to ensure reliable starting and driveability. In the coldest weather, as much as $49 \%$ gasoline is needed. In most U.S. climate zones, $30 \%$ gasoline is sufficient for much of the year. The latest ASTM specification, D5798-13a, specifies where and when the four different classes of fuel for FFVs should be used. Because of this variation in the ethanol percentage, many in research and industry have begun using the term "flex fuel" in lieu of "E85."

1. Wang, M., Wu, M., Huo, H. "Life-cycle energy and greenhouse gas emission impacts of different corn ethanol plant types." 


\section{Ethanol and E85 Properties, Specifications, and Information}

Also known as ethyl alcohol or grain alcohol, ethanol $\left(\mathrm{C}_{2} \mathrm{H}_{5} \mathrm{OH}\right)$ is an oxygenated hydrocarbon compound. In the United States, it is produced primarily from corn. The starch contained in the corn is converted into sugar and fermented to produce ethanol. The remainder of the corn (fiber and germ) is used as feed for livestock. Ethanol can also be produced from cellulose contained in plant-based materials, including corn stalks, wheat stalks, other agricultural or forestry waste, and municipal waste. Several processes are currently being developed for cellulose-derived ethanol, including enzymatic and acid hydrolysis and thermal processes. Cellulosederived ethanol is expected to be a necessary component to meeting various state and national renewable fuel standards.
While ethanol for beverages and ethanol for fuel are produced through similar processes, fuel ethanol is "denatured" by adding a minimum of $2 \%$ hydrocarbons, such as natural gasoline, to make it unfit for human consumption.

Ethanol is a flammable, colorless liquid with a faint alcohol odor. The color of ethanol/gasoline blends depends on the color of the gasoline in the blend. Blends may also have a gasoline-like odor. Descriptive properties of fuel ethanol and E85 are listed in Table 1. Table 2 compares the properties of E85 to those of ethanol and gasoline.

The chemical properties of ethanol must be accommodated to ensure proper engine performance, emissions,

\begin{tabular}{|c|c|}
\hline Property & Comment \\
\hline Vapor Density & $\begin{array}{l}\text { Ethanol vapor, like gasoline vapor, is denser than air and tends to settle in low areas. } \\
\text { Ethanol/gasoline blends, including E85, should be treated like gasoline blends with } \\
\text { respect to handling and safety. }\end{array}$ \\
\hline Solubility in Water & $\begin{array}{l}\text { Ethanol is extremely hydroscopic (i.e., attracts water). Water should be removed to the } \\
\text { extent possible from fuel ethanol handling, storage, and distribution equipment. A small } \\
\text { amount of water is soluble in E85, but at higher concentrations, the gasoline portion will } \\
\text { separate from the ethanol/water mixture. }\end{array}$ \\
\hline Energy Content & $\begin{array}{l}\text { For identical volumes, ethanol contains approximately } 30 \% \text { less energy than gasoline, } \\
\text { depending on the gasoline formulation. As a result, vehicle fuel economy of E85 can be } \\
\text { expected to be reduced by about } 25 \% \text {, depending on the gasoline formulation and the } \\
\text { individual vehicle. }\end{array}$ \\
\hline Flame Visibility & A fuel ethanol flame is less bright than a gasoline flame but is easily visible in daylight. \\
\hline Specific Gravity & Pure ethanol and ethanol/gasoline blends are slightly denser than gasoline. \\
\hline Conductivity & $\begin{array}{l}\text { Ethanol and ethanol blends have increased electrical conductivity compared to gasoline. } \\
\text { This can affect materials compatibility due to increased corrosion of certain metal junc- } \\
\text { tions and exposed electrical connections. }\end{array}$ \\
\hline $\begin{array}{l}\text { Air-Fuel } \\
\text { Ratio }\end{array}$ & $\begin{array}{l}\text { Due to the oxygen content in ethanol, the ideal, or "stoichiometric," air-fuel ratio for E85 } \\
\text { is a lower value than it is for gasoline (i.e., fewer pounds of air per pound of fuel). FFVs } \\
\text { are designed to detect ethanol and properly adjust the air-fuel ratio. }\end{array}$ \\
\hline Toxicity & $\begin{array}{l}\text { Pure ethanol in small amounts is not toxic and is not considered carcinogenic; however, } \\
\text { fuel ethanol and ethanol/gasoline blends must be treated as toxic and carcinogenic due } \\
\text { to the addition of hydrocarbons and gasoline. }\end{array}$ \\
\hline Flammability & $\begin{array}{l}\text { Depending on the hydrocarbon blending component, the vapor concentration in the } \\
\text { storage tank head space of many E85 blends can fall into the flammable range. This is a } \\
\text { concern primarily at low ambient temperatures. }\end{array}$ \\
\hline
\end{tabular}




\begin{tabular}{|l|c|c|c|}
\hline \multicolumn{4}{|c|}{ Table 2. Fuel Properties of Ethanol, Gasoline, and E85 } \\
\hline Property & Ethanol & Gasoline & E85* \\
\hline Chemical Formula & $\mathrm{C}_{2} \mathrm{H}_{5} \mathrm{OH}$ & $\begin{array}{c}\mathrm{C}_{4} \text { to } \mathrm{C}_{12} \\
\text { Hydrocarbons }\end{array}$ & $\begin{array}{c}\mathrm{C}_{4} \text { to } \mathrm{C}_{12} \text { Hydrocarbons and } \\
\text { Oxygenated Hydrocarbons }\end{array}$ \\
\hline Main Constituents (\% by weight) & $52 \mathrm{C}, 13 \mathrm{H}, 35 \mathrm{O}$ & $85-88 \mathrm{C}, 12-15 \mathrm{H}$ & $57 \mathrm{C}, 13 \mathrm{H}, 30 \mathrm{O}$ \\
\hline Octane (R+M)/2 & 113 & $86-94$ & $95-97$ \\
\hline $\begin{array}{l}\text { Lower Heating Value (Btu } \\
\text { per gallon) }\end{array}$ & 76,300 & 116,900 & $83,600-95,450$ \\
\hline $\begin{array}{l}\text { Miles per Gallon Relative } \\
\text { to Gasoline }\end{array}$ & $67 \%$ & - & $73 \% * *$ \\
\hline Reid Vapor Pressure (psi) & 2.3 & $7-16$ & $7-12$ \\
\hline Ignition Point-Fuel in Air (\%) & $3-19$ & $1-8$ & Varies \\
\hline Temperature (approx.) $\left({ }^{\circ} \mathrm{F}\right)$ & 850 & 495 & Varies \\
\hline Specific Gravity (60/65 $\left.{ }^{\circ} \mathrm{F}\right)$ & 0.794 & $0.72-0.78$ & 0.78 \\
\hline Air-Fuel Ratio (by weight) & 9 & 14.7 & 10 \\
\hline Hydrogen-Carbon Ratio & 3.0 & 1.85 & $2.75-2.95$ \\
\hline
\end{tabular}

${ }^{*}$ Depends on hydrocarbon blending component properties. $\quad{ }^{* *}$ Depends on both vehicle model and percentage ethanol in fuel.

fuel economy, and driveability under all operating conditions. Ethanol vaporizes at a lower temperature and within a narrower temperature range relative to many of the hydrocarbons in gasoline. To ensure proper cold-temperature start-up and warm-up operation in all regions of the United States during all seasons, ethanol is blended with hydrocarbons (typically gasoline) that are more volatile than ethanol.

Because of the lower energy content per gallon of ethanol relative to gasoline, vehicle fuel economy on E85 is typically about $25 \%$ less compared to gasoline (measured in miles per gallon). E15 and other blends have a proportional impact on fuel economy.

Most transportation fuel sold in the United States is manufactured to ASTM specifications. ASTM International is a voluntary consensus standards organization that creates and maintains fuel quality specifications established by committees composed of vehicle and engine manufacturers, fuel system equipment manufacturers, fuel producers, fuel users, and other interested parties, such as fuel quality regulators. ASTM standards are recognized by federal and most state government agencies as the primary means of ensuring fuel quality.
EPA and most states have passed regulations that require gasoline to meet all or a portion of the ASTM gasoline guidelines. Various specifications for ethanol, E85, and denaturant are available in Appendix B.

\section{Ethanol Blends}

\section{E85}

The properties of ethanol for E85 and other ethanol blends must meet ASTM D4806. The ASTM specification for E85 is ASTM D5798 "Specification for Ethanol Fuel Blends for Flexible-Fuel for Automotive SparkIgnition Engines" (see Table 3). The ethanol content of E85 is seasonally adjusted to improve vehicle cold-start and warm-up performance. The ethanol content can range from $51 \%$ to $83 \%$ by volume. Much like gasoline, the volatility of E85 is also adjusted seasonally and geographically by volatility class for vehicle cold-start and warm-up performance by increasing the proportion of light hydrocarbons during colder months. The seasonal and geographical volatility classes are determined by ASTM and contained in ASTM D5798. (A complete breakdown of geographical and seasonal volatility classes can be found in Appendix C.) 
The octane of E85 is much higher than that of gasoline, ranging from 95 to $97[(\mathrm{R}+\mathrm{M}) / 2]$, depending on its hydrocarbon content.

\section{E15}

EPA defines E15 as gasoline blended with $10.5 \%$ to $15 \%$ ethanol. In 2011, EPA approved E15 for use in model year 2001 and newer conventional vehicles, through a Clean Air Act waiver request based on significant testing and research. ${ }^{2}$ Stations are not required to sell E15.

\section{Vehicles approved for E15 use:}

- FFVs

- Model year 2001 and newer conventional cars, lightduty trucks, and medium-duty passenger vehicles.

\section{Vehicles prohibited from using E15:}

- All motorcycles

- All vehicles with heavy-duty engines, such as school buses, transit buses, and delivery trucks

- All off-road vehicles, such as boats and snowmobiles

- All engines in off-road equipment, such as lawnmowers and chain saws

- All model year 2000 and older conventional cars, light-duty trucks, and medium-duty passenger vehicles.

There are several requirements and regulations that service stations must adhere to when selling E15. These requirements and regulations were determined by EPA. The most significant requirements are implementation of a misfueling mitigation plan (MMP) and registration for the annual fuel survey. Misfueling is a concern for vehicles older than model year 2001, and an MMP reduces the risk of misfueling.

EPA requires an annual fuel quality survey that checks for ethanol content. This survey is conducted by an independent third party and includes random sampling at stations. Any retail station may be sampled regardless of the fuels it offers. For stations selling E15, Reid vapor pressure is checked, as is the presence of required labels on the dispenser. Unacceptable results from this survey may cause a Possible Non-Compliance notice. Any station receiving a Possible Non-Compliance notice must respond to EPA.

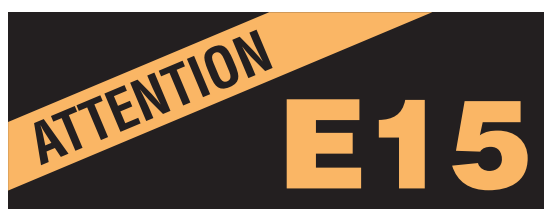

Up to $15 \%$ ethanol

\section{Use only in}

- 2001 and newer passenger vehicles

- Flex-fuel vehicles

Don't use in other vehicles, boats or gasoline-powered equipment. It may cause damage and is prohibited by federal law.

\section{Requirements to offer E15:}

- Fuel producers that sell E15 are required to individually register with EPA (many have already done so).

- Retail stations must have an EPA-approved MMP if blending E15. The Renewable Fuels Association (RFA) provides a model MMP to any station wishing to sell E15. ${ }^{3}$

- An EPA-approved E15 label must be affixed to the dispenser.

- Product transfer documents must accompany all deliveries of fuel for E15 use.

- The retail station must participate in the fuel quality survey; register at www.rfgsa.org.

- Ethanol used for E15 must meet ASTM D4806-10; Reid vapor pressure is limited to 9.0 psi in the summer.

- Stations must use dispenser and hose configurations that have been approved by EPA. Options include the following:

- A dedicated E15 hose; or

- A shared E0/E10/E15 hose, which requires a purchase of four gallons minimum ("four gallons minimum" label must be displayed), or at least one dedicated E10 hose.

2. www.epa.gov/otaq/regs/fuels/additive/e15/

3. "Renewable Fuels Association Model E15 Misfueling Mitigation Plan." EPA OTAQ. March 2, 2012. 


\begin{tabular}{|c|c|c|c|c|}
\hline \multirow{2}{*}{$\begin{array}{l}\text { Property } \\
\text { ASTM Volatility Class }\end{array}$} & \multicolumn{4}{|c|}{ Value for Class } \\
\hline & 1 & 2 & 3 & 4 \\
\hline \multirow[t]{2}{*}{ Vapor Pressure (psi) } & $5.5-8.5$ & $7.0-9.5$ & $8.5-12.0$ & $9.5-15.0$ \\
\hline & \multicolumn{4}{|c|}{ All Classes } \\
\hline Sulfur (maximum, mg/kg) & \multicolumn{4}{|c|}{80} \\
\hline Ethanol Content (volume \%) & \multicolumn{4}{|c|}{$51-83$} \\
\hline Methanol (maximum, volume \%) & \multicolumn{4}{|c|}{0.5} \\
\hline Water (maximum, mass \%) & \multicolumn{4}{|c|}{1} \\
\hline Acidity as Acetic Acid (maximum, mg/kg) & \multicolumn{4}{|c|}{40} \\
\hline Inorganic Chloride (maximum, mg/kg) & \multicolumn{4}{|c|}{1} \\
\hline Gum, Unwashed (maximum, mg/100 mL) & \multicolumn{4}{|c|}{20} \\
\hline Gum, Solvent-Washed (maximum, mg/100 mL) & \multicolumn{4}{|c|}{5} \\
\hline Copper (maximum, mg/100 mL) & \multicolumn{4}{|c|}{0.07} \\
\hline Appearance & \multicolumn{4}{|c|}{$\begin{array}{l}\text { Product shall be visibly free of suspended or precipitated } \\
\text { contaminants (shall be clear and bright). }\end{array}$} \\
\hline
\end{tabular}

Stations that plan to dispense E15 should install hanging hardware that is UL listed for blends up to E25 or up to E85 (UL does not have a separate listing for E15; the E25 listing ensures that today's equipment can accommodate future ethanol blends that may be higher than E15). Dispenser retrofit kits, which allow E15 to be sold in existing dispensers, are available from Gilbarco. The Encore E25 Retrofit Kit includes a meter and valve assembly that enables easier installation. Wayne retrofit kits are expected in late 2013. Gilbarco and Wayne standard warranties apply to existing dispensers selling E15. Refer to RFA's E15 Retailer Handbook for more information. ${ }^{4}$

As of 2013, E15 is not widely available. It is sold in a few Midwestern states by stations that already offer E85.

\section{Blender Pumps}

Blender pumps are fuel dispensers that draw fuel from two separate bulk storage tanks and can dispense preprogrammed blends of those fuels into vehicles. Many stations already use blender pumps to create midgrade gasoline from a blend of regular and premium gasoline. In ethanol applications, blender pumps allow station owners to blend E85 with conventional gasoline to create mid-level ethanol blends. ASTM has developed a standard practice for blending mid-level ethanol fuels for FFVs. ${ }^{5}$

Blender pumps offer FFV owners a variety of ethanolblended gasoline products between E15 and E85. E20 (20\% ethanol, $80 \%$ gasoline) and E30 (30\% ethanol, $70 \%$ gasoline) are most common. Stations offering blenderpump blends to FFV owners are concentrated in the Midwest. As of March 2013, about 345 stations offered mid-level ethanol fuels through blender pumps. Blender pumps may also be used to legally dispense E15.

UL-listed dispensers are available from Gasboy, Gilbarco, and Wayne. Stations with blender pumps should use UL-listed E85 hanging hardware (see Appendix D). Labels must clearly indicate that midlevel ethanol blends from blender pumps are only for FFVs. It is not recommended that stations store E98 for blending due to its flammability risks (see next page for more information on ethanol flammability).

\footnotetext{
4. "E15 Retailer Handbook." Renewable Fuels Association. 2012. Accessed April 18, 2013: http://ethanolrfa.3cdn. net/62e6e5d16c896ef941_tzm6vusyl.pdf

5. www.astm.org/Standards/D7794.htm
} 


\section{Hydrocarbons}

Unleaded gasoline is typically used to blend E85, but higher-volatility components such as natural gasoline (a high-volatility, low-octane liquid byproduct of natural gas production) can also be used to meet ASTM volatility requirements. These requirements serve to reduce the occurrence of flammable vapor regimes (and explosion hazard) in fuel tanks.

Because of the different types of hydrocarbon components used in E85, its range of vapor flammability in tanks is wider than that of gasoline. The National Renewable Energy Laboratory (NREL) compared the fuel tank headspace flammability of seven E85 fuel blends, two gasoline samples, and denatured ethanol. ${ }^{6}$ Headspace vapors for the two gasoline samples became flammable when the temperature dropped to approximately $-19^{\circ} \mathrm{C}\left(-2^{\circ} \mathrm{F}\right)$ and $-25^{\circ} \mathrm{C}\left(-13^{\circ} \mathrm{F}\right)$ or lower. The E85 blends, on the other hand, produced flammable vapors at temperatures below values ranging from $-2^{\circ} \mathrm{C}\left(28^{\circ} \mathrm{F}\right)$ to $-22^{\circ} \mathrm{C}\left(8^{\circ} \mathrm{F}\right)$. Denatured ethanol was found to be flammable at room temperature and all temperatures down to approximately $-6^{\circ} \mathrm{C}\left(22^{\circ} \mathrm{F}\right)$. Therefore, stations should not store denatured ethanol for blending E85 or other ethanol blends, due to the risk of explosion.

\section{Fuel Additives}

According to EPA regulations, all commercial grades of gasoline must contain specified levels of additives, detergents, and corrosion inhibitors. ASTM D5798 does not provide specific levels of denaturant, corrosion inhibitor, or deposit control additives. Ethanol production plants add a corrosion inhibitor at a level that assumes the ethanol will be blended as E10; this level of corrosion inhibitor exceeds what is needed for E85.7 Detergents or deposit control additives may be needed to ensure deposits do not form in the vehicle fuel injection system. Blenders or terminals should engage additive manufacturers to determine whether the additives will remain soluble with various concentrations of ethanol and gasoline.

\section{Fuel Quality}

NREL and the Coordinating Research Council (CRC) collaborated to survey E85 quality in 2008-2009 and 2011 and mid-level blends from blender pumps in 2012 and 2013. These surveys have shown improvement in E85 quality, likely as a result of the reduction in minimum ethanol content allowed in D5798, which raises the vapor pressure of the finished blend. The blender pump survey showed that the vapor pressure

\section{Ethanol Production, Blending, and Distribution}

- Ethanol is produced at an ethanol plant. Prior to being transported, the fuel must be denatured by adding approximately $2 \%$ hydrocarbons, such as natural gasoline, to render it unfit for human consumption. A corrosion inhibitor is also added.

- The denatured ethanol is transported by rail, truck, or barge to the fuel supplier.

- Denatured ethanol is dispensed into the fuel supplier's ethanol storage tank in the same manner as gasoline and diesel fuel.

- A fuel carrier orders a tanker of E85.

- The fuel carrier delivers E85 to the retail fuel marketer for sale to the public.

of E20 blends was statistically similar to that of the gasolines tested. NREL and CRC are continuing their collaborations for additional surveys that are expected to be completed in the future. Additional E85 CRC fuel quality survey data can be obtained from CRC Report Nos. E-79 and E-79-2. ${ }^{8}$

\section{Materials Recommendations}

As with all motor fuels, it is important to maintain proper fuel handling and housekeeping practices to minimize contamination. Certain materials commonly used with gasoline may be incompatible with mid- and high-level alcohol blends. 9 , 10 Some materials may

6. Gardiner, D., Bardon, M. "An Experimental and Modeling Study of the Flammability of Fuel Tank Headspace Vapors from High Ethanol Content Fuels." National Renewable Energy Laboratory. February 2008.

7. "E85 Fuel Ethanol Industry Guidelines, Specifications, and Procedures." Renewable Fuels Association. March 2009.

8. Coordinating Research Council Recent Reports and Study Results; CRC Reports No. E-85, National Survey of E85 Fuel Quality; No. E-65-3, Fuel Permeation; No. E-67, Ethanol Effects on Exhaust Emissions; and Nos. E-79 and E-79-2, Study of E85 in the U.S.

9. Kass, M., Theiss, T. "Compatibility Study for Plastic, Elastomeric, and Metallic Fueling Infrastructure Materials Exposed to Aggressive Formulations of Ethanol-Blended Gasoline." Oak Ridge National Laboratory. May 2012.

10. Coordinating Research Council. CRC Reports No. E-65-3, Fuel Permeation; No. E-67, Ethanol Effects on Exhaust Emissions; and Nos. E-79 and E-79-2, Study of E85 in the U.S. 


\section{Table 4. Flammability Limits of Gasoline and Ethanol}

\begin{tabular}{|l|c|c|}
\hline Fuel Gas & $\begin{array}{c}\text { Lower Explosive or Flammable Limit } \\
\text { (LEL/LFL) (\% in air) }\end{array}$ & $\begin{array}{c}\text { Upper Explosive or Flammable Limit } \\
\text { (UEL/UFL) (\% in air) }\end{array}$ \\
\hline Gasoline & 1.4 & 7.6 \\
\hline Ethanol & 3.3 & 19 \\
\hline
\end{tabular}

degrade over time, potentially leading to equipment problems. They may also contaminate the fuel, which may adversely affect vehicle fuel system operation or cause component malfunction and lead to degraded driveability and performance.

Ethanol blends may impact metallic and elastomer materials in fueling systems. To address these issues, manufacturers have upgraded materials and developed products that are compatible with blends up to E25 or with blends up to E85. Many elastomer materials have been changed in fueling equipment to accommodate a range of fuels (including ethanol blends and ultra-low sulfur diesel) and in anticipation of additional alternative fuels entering the market. Only ethanolcompatible materials should be used in storage and dispensing systems.

E85 acts like a cleaning agent and will initially mobilize sludge in storage tanks. E85 can also cause corrosion of some soft metals and reduce the tensile strength of some nonmetallic materials. Zinc, brass, lead, and aluminum have shown sensitivity to degradation with E85. Terneplated steel (lead-tin alloy coating), which has been commonly used for vehicle fuel tanks, and lead-based solder are also incompatible with E85. Use of these metals should be avoided. Unplated steel, stainless steel, black iron, and bronze have shown acceptable resistance to E85 corrosion. Blends below E25 do not cause corrosion of metals.

Nonmetallic materials that degrade when in contact with fuel ethanol include natural rubber, polyurethane, cork gasket material, leather, polyvinyl chloride, nylon 6/6, methyl-methacrylate plastics, and certain thermoplastic and thermoset polymers. Blends below E25 may impact elastomers, and contact with E85 causes some elastomers to swell. Nonmetallic materials successfully used for transferring and storing ethanol include thermoset-reinforced fiberglass, thermoplastic piping, and thermoset-reinforced fiberglass tanks (as listed for this application by UL). 


\section{Storing and Dispensing Ethanol Blends}

Like gasoline, alcohol-based fuels are liquid at ambient pressures and temperatures. The equipment used to store gasoline and diesel fuels is the same equipment used for alcohol-based fuels, with modifications in some materials. Above-ground dispensing equipment must be designed specifically for ethanol blends.

Although fuel-related vehicle problems due to ethanolblended gasoline are rare, most recent problems have been related to contaminated fuel. Consequently, choosing the right materials for fuel storage and dispensing systems and following proper fuel-handling procedures are crucial for proper vehicle operation.

Most vehicles in the United States have onboard refueling vapor recovery, negating the need for vapor recovery in fueling equipment. As of May 2012, EPA no longer requires Stage II vapor recovery systems at gasoline dispensing facilities located in nonattainment areas for ozone. ${ }^{11}$ In December 2006, EPA issued a guidance letter stating that the impact of not using Stage II vapor recovery equipment would be minimal, as nearly all FFVs have onboard vapor recovery systems. ${ }^{12}$ However, some states still require Stage II vapor recovery equipment; state regulatory authorities should be contacted to determine applicability in each situation.

This handbook provides checklists detailing key items to consider when adding or converting equipment to dispense E15 and E85 (pages 19 and 21).

In addition to the information provided in this document, the U.S. Department of Energy has compiled a collection of case studies documenting successful implementation of ethanol fueling infrastructure. ${ }^{13}$

\section{Using Existing Fueling Systems}

\section{Tanks}

In many cases, existing gasoline and diesel fuel systems may also be used to store ethanol blends. It is important for a service station to first determine what type of underground storage tank (UST) systems it has.

EPA's Office of Underground Storage Tanks regulates tanks storing petroleum and biofuels under Subtitle I of the Solid Waste Disposal Act. Per federal regulations (Code of Federal Regulations Title 40 Part 280 [40 CFR
280]), USTs must be compatible with the fuel stored. States administer the UST program, and compatibility is the responsibility of the tank owner.

In 2010, EPA's Office of Underground Storage Tanks published the guidance document, "Compatibility of Underground Storage Tank Systems with Biofuels Blends," which provides a path for achieving compliance when storing biofuels above E10 or B20 (20\% biodiesel). ${ }^{14}$ UST requirements have generally mandated third-party certification of equipment (typically conducted by UL). UL 58 is the testing standard for steel USTs. It does not require equipment materials to be exposed to test fluids. UL 1316 is the testing standard for fiberglass USTs and allows listings for up to E100 (neat ethanol). The guidance allows manufacturers to provide a signed letter affirming a tank's compatibility with biofuel blends. All existing tank manufacturers have provided such statements. Requirements contained in the guidance are expected to be included in the final 40 CFR 280 rule in early 2014.

The Steel Tank Institute issued a statement that all steel tanks are compatible with all ethanol blends up to E100. In addition, all steel tank manufacturers have provided individual letters affirming compatibility with E100. There are two fiberglass tank companies: Containment Solutions has UL listings for all tank products for E100; Xerxes approves the storage of E100 in single-wall tanks manufactured after July 2005 and in double-walled tanks manufactured since April 1990.

According to U.S. Department of Transportation Office of Pipeline Safety compatibility regulations, all USTs and aboveground storage tanks (ASTs) must be made of or lined with materials that are compatible with the substance stored. Compatibility is defined as the ability of two or more substances to maintain their respective physical and chemical properties upon contact with one another for the design life of the tank system under

\footnotetext{
11. "Guidance on Removing Stage // Gasoline Vapor Control Programs from State Implementation Plans and Assessing Comparable Measures." EPA. August 7, 2012.

12. "Removal of Stage I/ Vapor Recovery in Situations Where Widespread Use of Onboard Refueling Vapor Recovery is Demonstrated." EPA Memorandum.

13. www.afdc.energy.gov/fuels/ethanol_infrastructure.html 14. www.epa.gov/oust/altfuels/biofuelsguidance.htm
} 


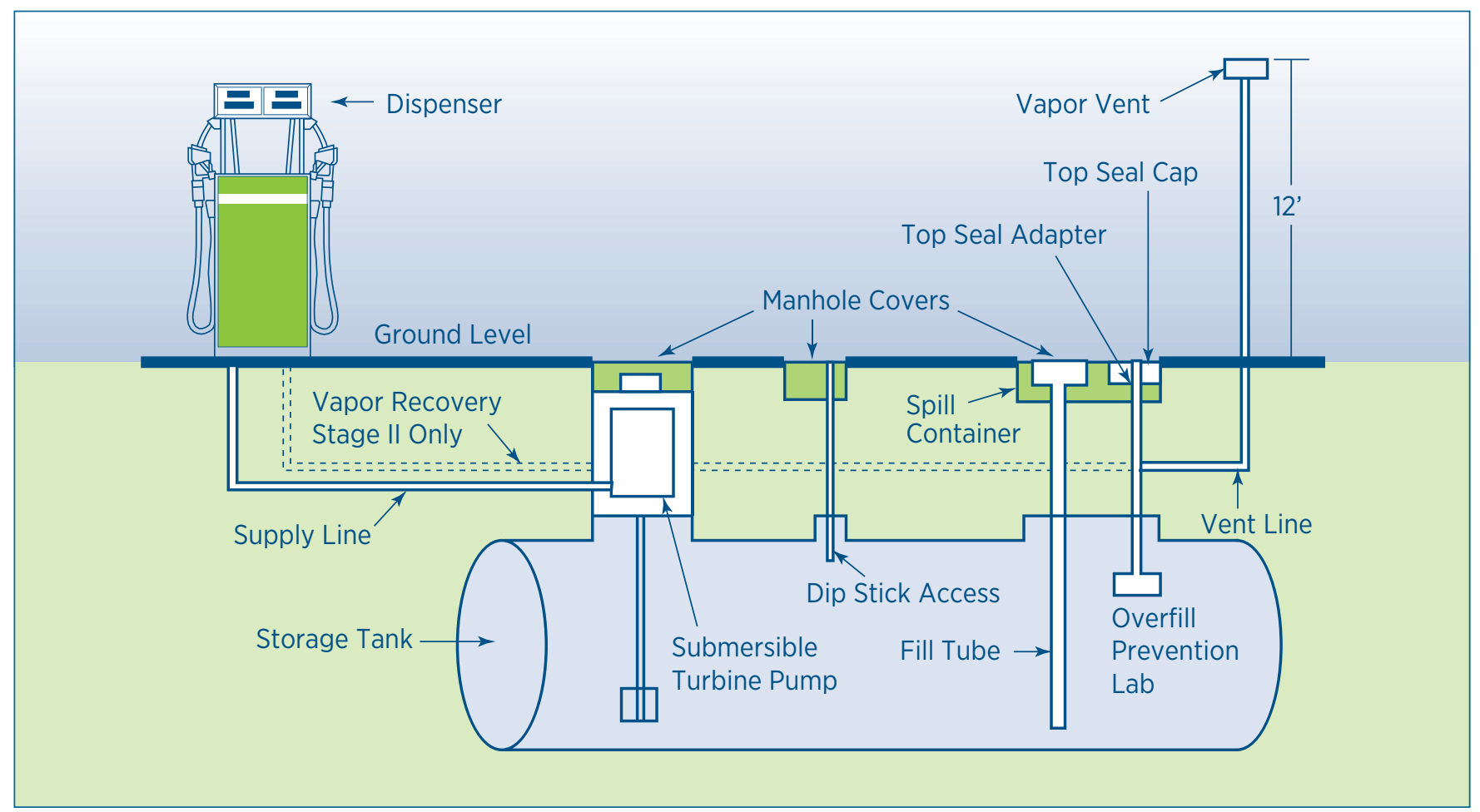

Figure 1. Typical Fuel Dispenser and Underground Storage Piping. I/lustration by NREL

conditions likely to be encountered. Product piping, including that within the dispensers, is considered part of the UST or AST system and needs to be compatible with the substance stored and dispensed through it. The guidance in American Petroleum Institute (API) publication 1626, "Storing and Handling Ethanol and Gasoline Blends at Distribution Terminals and Service Stations," may be used to comply with the compatibility requirements in the regulations.

As part of the planning process for any fuel storage system, local building and fire codes must be checked. While E85 and ethanol blends fall under the same handling and storage requirements as gasoline within the provisions of National Fire Protection Association (NFPA) Standards 30 and 30A, local fire provisions and regulations must be considered, including the use of ULlisted dispensers. The International Fire Code (IFC) also provides codes for fuel storage. For more information, see the Safety Codes section of this handbook (page 17).

Aboveground Tanks: Steel ASTs are used to store E85 and can also be used to store E15. ASTs are typically constructed of stainless steel or carbon steel. The use of galvanized metal tanks or plastic tanks is not recommended. It is important to check with local and national fire codes to determine appropriate tank construction. Many jurisdictions will require two-hour fire-rated tank technology to dispense fuels from ASTs into motor vehicles. The construction of the tank may determine where the dispenser can be mounted and how close the tank can be to nearby buildings and property lines.

Cleaning Tanks: Tanks previously used for storing other types of fuel may be used for E85 if the tank is properly cleaned first. During storage, debris and moisture can build up over time to form sludge or "water bottoms." Because ethanol is soluble in water, when E85 or another ethanol blend is introduced to a previously used petroleum fuel storage tank, the ethanol will mix with the water bottoms, and the solvent action of ethanol will remove any sludge buildup and contaminate the fuel. More than 25 years of experience in handling lowlevel ethanol blends has helped industry understand how to address the accumulation of debris and water in the fuel distribution and storage system. However, proper housekeeping procedures should be instituted to limit debris and water contamination.

There are several methods for cleaning sludge from storage tanks, which are listed below. It is possible to inspect a tank prior to cleaning using a camera with a remote that is inserted into a tank. It is important to note that all of the methods should be completed by a qualified company familiar with cleaning petroleum storage tanks. 
- Optic Sweep: This patented system uses a fiber optic camera and controllable probe with an extraction device that can visually inspect and clean fuel storage tank bottoms at any fuel level with no tank downtime. The optic sweep can locate and remove water, sludge, bacteria, rust particles, and sediment while customers continue to pump.

- Steam Cleaning: A person physically enters the tank, steam cleans it, and removes sludge. Care must be taken to properly dry the tank.

- Filter Agitator: An agitating device is lowered into the tank. The fuel and any debris are agitated and circulated. A filtration system removes the suspended debris.

- Chemical Solvents: Chemical solvents are used to remove scale and debris. Liquid and debris are then pumped from the tank and disposed of.

Choosing the appropriate cleaning technique will depend upon the type of fuel that has been stored in the tank, availability of the service, and state and local environmental regulations.

General Storage Considerations: Many of today's new service station owners install large ethanol-compatible USTs with several compartments built into the tanks. The compartments allow several fuel products to be stored and dispensed.

UST installations are normally intended to be permanent, whereas ethanol fuel blend ASTs can be installed as an addition to an existing fueling facility or as new storage for fleets on private property, with an ability to be relocated. ASTs are usually smaller than USTs when used for ethanol fuel blends, with the installed capacity dependent on the demand anticipated.

\section{UL Listing}

Authorities having jurisdiction (AHJs) and permitting offices typically require UL-listed fueling equipment. UL developed Subject 87A for testing fuel dispensers, hanging hardware, and other related equipment with ethanol blends above E10 (covered by the older standard, UL 87). Development of 87A included fuel exposure for 15 weeks at elevated temperature, followed by performance testing. The tests were originally developed for E85 equipment but were amended with an additional test fluid of E25 to also address needs for equipment to accommodate blends up to E25. Notably, UL lists the blending mechanism in blender pumps, in addition to the pump itself.

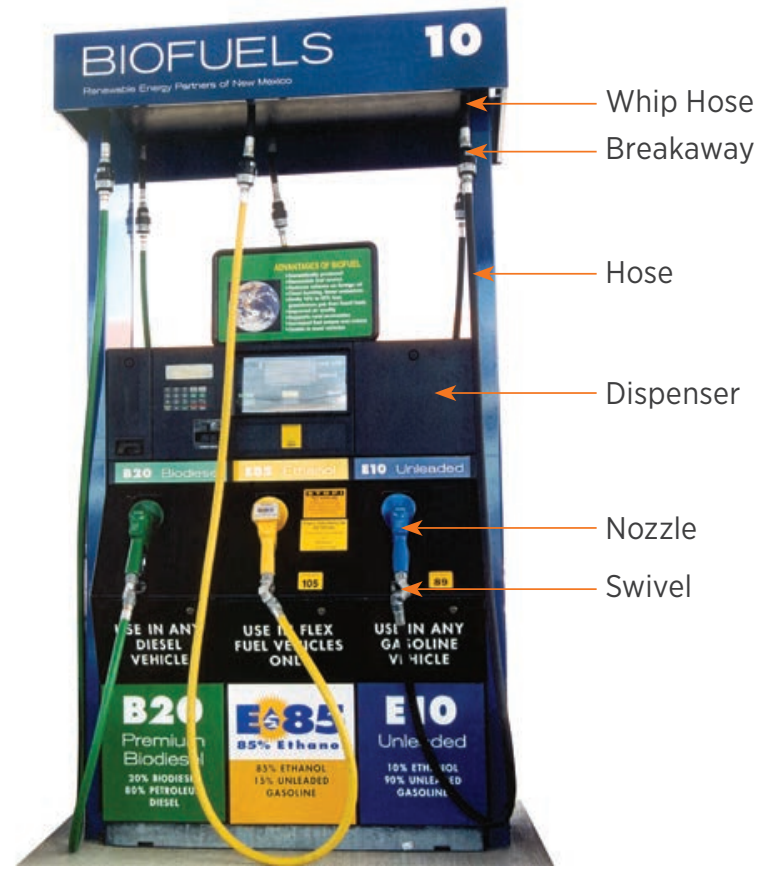

Figure 2. Dispenser and Hanging Hardware. Photo by Charles Bensinger, NREL 13531

Dispenser manufacturers have developed retrofit kits to meet UL standards to sell E15 in existing dispensers. This involves replacement of the meter assembly and several gaskets and valves. UL tested Gilbarco and Wayne retrofit kits with E25 (E15 is not offered as a certification fuel) and evaluated the manufacturers' installation guides. Gilbarco's retrofit kits are listed by UL. Wayne's retrofit kits have completed testing but were not yet listed at the time this guide was prepared. A complete list of UL-listed E85 equipment is available in Appendix D.

Many jurisdictions allow an alternate equivalent dispenser design to be submitted for approval. Each jurisdiction has its own process and discretion in granting variances or waivers to approve designs that are not UL certified.

\section{Dispensers}

As a general rule, E85 dispensers must use iron, unplated or stainless steel, or other suitably applied and tested materials in the fuel path. For vane-type pumps, impellers made from soft metals (such as zinc, brass, lead, or aluminum) should be avoided. Steel or an engineered polymer with a high chemical resistance is recommended for best results. Dispensers for E25 must use compatible elastomers; specialized metals are not necessary. Use of non-compatible dispenser materials may lead to leaks, premature meter inaccuracies, 
and introduction of contaminants into the fuel. Table 5 shows dispensers listed for use with E85. Manufacturers of E10-listed dispensers include E15 as an allowable fuel in their two-year standard warranties. UL-listed E25 dispensers are expected in 2013; they will be less expensive than E85 dispensers, as specialized metals are not required.

\section{Hanging Hardware}

The hanging hardware consists of the nozzle, swivel, hose, whip hose, and breakaway. Table 6 shows hanging hardware listed for use with E25 and E85. Stations dispensing blends over E10 should purchase and install UL-listed hardware for up to E25 or up to E85 (depending on the fuel dispensed). UL 87A also covers submersible turbine pumps, which convey fuel from the tank to the dispenser, and shear valves, which cut off the flow of the fuel if there is an incident with a dispenser. A complete list of UL-listed ethanol equipment is available in Appendix D.

As previously noted, components made from zinc, brass, lead, aluminum, or other soft metals should be avoided when dispensing E85. Fuel ethanol may degrade such soft metals, which may cause leaks and contaminate the fuel, leading to deposits in the vehicle fuel system and possibly impairing vehicle performance and causing safety concerns.

\section{Other Equipment}

\section{Fill Pipes and Associated Equipment}

Fuel enters the UST dispensing system from the fuel delivery truck through a fill pipe, using a drop hose. Ethanol-compatible drop hoses are available from several manufacturers. Fuel enters ASTs through a pump. In recent years, many component manufacturers have converted gaskets, tubes, adapters, and piping to be compatible with ethanol-blended gasoline and E85. Anodized coatings or components made of cast-iron or stainless steel are available for use with E85.

\section{Pumps and Leak-Detection Equipment}

Pressurized and suction fueling systems require different types of leak-detection equipment. Suction systems have a pump within the fuel dispenser, while pressurized pumps push the fuel from the tank to the dispenser. Typically, pressurized systems require both continuous and periodic leak detection tests, as well as other line tightness testing. If a suction system has a check valve solely at the dispenser, leak detection testing may not be required, and possibly, fewer line tests will be required.

\section{Table 5. UL-Listed E85 Dispensers}

\begin{tabular}{|l|l|}
\hline Manufacturer & Model* \\
\hline Wayne & G520 \\
\hline Wayne & G610 \\
\hline Wayne & G620 \\
\hline Wayne & Ovation E \\
\hline Gilbarco & Encore 300 \\
\hline Gilbarco & Encore 500 \\
\hline Gilbarco & Encore 550 \\
\hline Gilbarco & Encore 700 \\
\hline Gilbarco & Encore NJ2 \\
\hline Gilbarco & Encore NJ4 \\
\hline Gilbarco & Encore NL3 \\
\hline Gasboy & Atlas E85 \\
\hline
\end{tabular}

*See Appendix D for detailed model numbers.

\begin{tabular}{|l|l|l|l|}
\hline \multirow{2}{*}{ Equipment } & \multirow{2}{*}{ Manufacturer } & \multicolumn{2}{c|}{ Model } \\
\cline { 3 - 4 } & & E85* & E25 \\
\hline Breakaway & OPW Fueling Systems & 66 V-0492 & 66 V-0300 \\
\hline Hose & Veyance & Flexsteel Futura Ethan-all & - \\
\hline Nozzle & OPW Fueling Systems & 21GE and 21GE-A & - \\
\hline Swivel & OPW Fueling Systems & 241TPS-0492 & 241TPS-0241, 241TPS-1000, 241TPW-0492 \\
\hline
\end{tabular}

${ }^{*}$ All E85 equipment is also UL listed for E25. 


\section{Piping}

Nonmetallic, corrosion-proof pipe is recommended for underground piping. According to UL Standard 971 ("Standard for Nonmetallic Underground Piping for Flammable Liquids"), products that have been tested for compatibility with high-concentration alcohol blends (ethanol and methanol) should be used. Schedule 40 black-iron pipe and galvanized pipe may be used but will require corrosion protection. Pipe-thread sealant, when needed, must be a Teflon tape or Teflon-based pipe-thread compound. If secondary piping is needed, thermoset-reinforced fiberglass or thermoplastic double-wall piping should be used.

\section{Fuel Filters}

The dispenser filter is the last line of defense before the fuel reaches a vehicle's tank. Typically, a 30-micron filter is used with diesel fuel, and a 10-micron filter is used with gasoline and low-level ethanol blends. E85 and blender pump dispensers should have filters with a nominal rating of $50 \%$ for particles 5 microns or larger and an absolute rating of $99 \%$ for particles 10 microns or larger. These ratings mean the filter can capture the given percentage of the particles of the stated size.

Multi-pass testing recently replaced previous rating methods and is recognized by SAE International and other industry organizations. Multi-pass testing is used to count the number of particles of a given size before and after fluid passes through a filter. From these measurements, a Beta ratio is formulated by dividing the number of particles upstream by the number of particles downstream. E85 and blender pump dispenser filters should have a Beta ratio of 100 for 10 -micron particles and a ratio of 2 for 5 -micron particles.

\section{Fittings and Connectors}

To avoid degradation, all fittings, connectors, and adapters that will be in contact with the fuel should be made of materials such as stainless steel, black iron, or bronze. If aluminum or brass fittings are used, they must be nickel-plated to avoid any contact between the bare metal and the fuel, to avoid corrosion. The surface plating should be inspected periodically for evidence of degradation. 
Most states, departments of transportation, and AHJs require specific E15- and E85-related signage at fueling stations. Contact the appropriate official in your area to determine the required signage. Labels are available free of charge from Blend Your Own (www.byoethanol.com/ dispenser-labels-available.html). API Recommended Practice 1637 states that storage tanks containing E85 must be labeled on all fillboxes and fillbox covers with a bronze pentagon, as shown below at right, and "E85" printed in black or white in the middle of the pentagon. States may have additional labeling requirements.

\section{E15 Labels}

Per EPA, an E15 label must be placed on the upper two-thirds of a dispenser. If the dispenser has one nozzle, the E15 label must be placed above the button or control for selecting E15. For a multi-hose dispenser, the label must be placed where it is immediately visible to the consumer. If a common hose is used to dispense E0, E10, and E15, the four-gallon minimum sign must be posted on the dispenser.

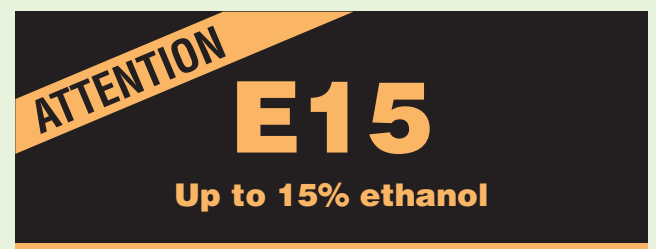

\section{Use only in}

- 2001 and newer passenger vehicles

- Flex-fuel vehicles

Don't use in other vehicles, boats or gasoline-powered equipment. It may cause damage and is prohibited by federal law.

\section{Minimum Fueling Volume 4 Gallons:}

Dispensing Less May Violate Federal Law

\section{E85 Labels}

E85 labels should be placed on fillboxes and fillbox covers in one of the following ways:

- Paint the decal on the top of the fillbox cover or on the rim of the fillbox

- Attach a tag to the fillpipe adapter

- Screw a tag into the fillbox rim

- Fit a plastic or fiberglass insert into the rim of the fillbox.

In addition, the Federal Trade Commission requires that a small sticker be placed on the face of the fuel dispenser as close as possible to the price per unit of fuel.

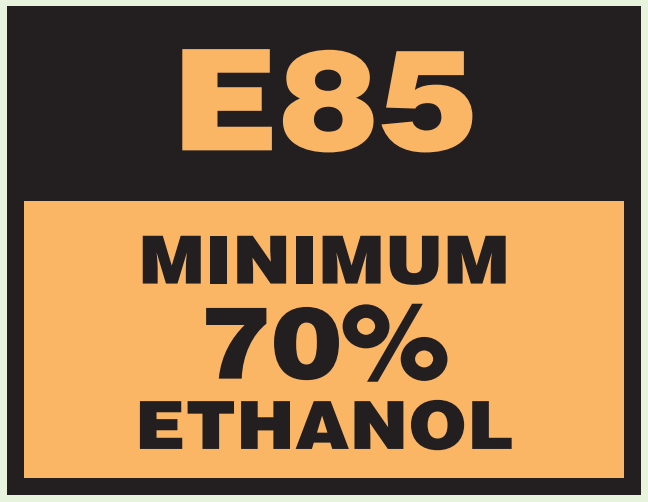

FTC Label

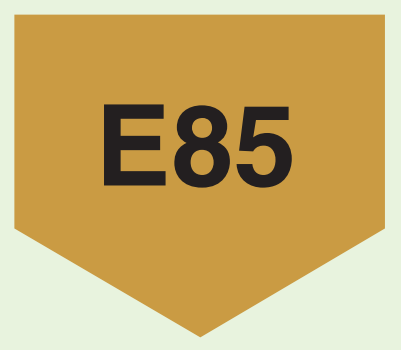

API Label 


\section{Ethanol Blend}

\section{Quality Assurance}

Following the installation of an E15, E85, or blender pump dispenser, several operational precautions can help assure fuel quality. Periodically checking the fuel properties will avoid damage to vehicles. Some of these checks may be performed in the field, but others may require the services of a specialized laboratory. At a minimum, the following items should be checked every one to two months, depending on how frequently the station is used:

- Electrical conductivity (see Appendix E)

- Particulate content

- Hydrocarbon content (see Appendix E)

- Water content

- Reid vapor pressure.

\section{Shipping Procedures}

Your fuel provider may be able to recommend a laboratory in your area that can perform periodic fuel quality analysis. To safely and legally ship a sample of fuel, follow all hazardous material shipping requirements and include the following information on the outside of the package:

- U.S. Department of Transportation Shipping Name: Alcohol n.o.s. (ethanol, gasoline)

- Identification Number: UN 1987

- Diamond Labels: Flammability 3

- Label: Flammable Liquid

- Arrow Label: This End Up.

Be sure to use ethanol-compatible shipping containers, including the box holding the container, specifically designed for this purpose.

\section{Safety Procedures}

\section{Health Considerations}

Fuel ethanol should be handled in the same manner as gasoline. Personal exposure should be minimized. Like gasoline, fuel ethanol is flammable and may contain additives that can be harmful even with casual contact. Fuel ethanol is poisonous and should not be ingested.

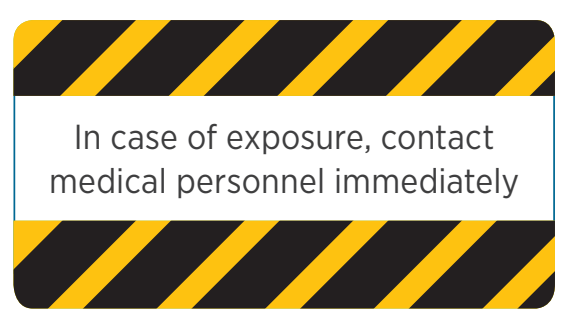

Exposure to fuel ethanol can occur by inhalation (breathing in its vapors), absorption (contact with the skin or the eyes), or ingestion (swallowing). The various symptoms of exposure to fuel ethanol are shown in Table 7 on page 17.

\section{Fire Safety Considerations}

Fuel ethanol fires require specific equipment, materials, and training. In 2007, the Ethanol Emergency Response Coalition sponsored fire-fighting agent testing using the UL 162 test methodology. The results showed that conventional gasoline fire-fighting methods and chemicals are insufficient for fighting fires fueled by ethanol blends higher than E10. Only foams containing an alcoholresistant polymer should be used, and only foams classified as AR-AFFF passed all UL requirements. These recommendations should be applied to all ethanol blends, including low-level blends such as E6 and E10, E15, and high-level blends such as E85.

Before constructing any fueling installations, the local fire marshal should be consulted to determine local regulations governing safe fuel ethanol handling procedures. 


\section{Table 7. First Aid Treatments for Exposure to Fuel Ethanol}

\begin{tabular}{|c|c|c|}
\hline \multicolumn{3}{|c|}{$\begin{array}{l}\text { - Dullness of memory and concentration } \\
\text { - Impaired motor coordination } \\
\text { - Drowsiness, stupor, and coma }\end{array}$} \\
\hline Exposure & First Aid Treatment & $\begin{array}{l}\text { Treatment Compared to } \\
\text { Gasoline Exposure }\end{array}$ \\
\hline Inhalation & $\begin{array}{l}\text { Move away from the vapors to fresh air, and contact medical } \\
\text { personnel immediately. }\end{array}$ & Same \\
\hline Skin Absorption & $\begin{array}{l}\text { Immediately wash skin with soap, and flush skin with plenty of } \\
\text { water for at least } 15 \text { minutes. Remove contaminated clothing, } \\
\text { and contact medical personnel. }\end{array}$ & Same \\
\hline Eye Absorption & $\begin{array}{l}\text { Immediately flush eyes with plenty of water for at least } 15 \\
\text { minutes, and contact medical personnel. }\end{array}$ & Same \\
\hline Ingestion & $\begin{array}{l}\text { Lie down, keep warm, do not induce vomiting, and contact } \\
\text { medical personnel immediately. }\end{array}$ & Different \\
\hline
\end{tabular}

"Responding to Ethanol Incidents," a video developed in conjunction with RFA, the International Fire Chiefs Association, General Motors, Independent Liquid Terminals Association, ANSUL Innovative Fire Solutions, and Williams Fire and Hazard Control, is a technical presentation directed primarily at ethanol plant operators and first responders. It is a training tool that documents ethanol fire-fighting foam test results and educates viewers on how to deal with ethanol-related spills and fires. In addition, the film explores how ethanol-blended fuels are produced and distributed. RFA provides the video in several formats as well as other pertinent safety training manuals..$^{15}$

\section{Safety Codes}

Safety standards for handling and storing E85 are the same as those for gasoline. NFPA has two standards that apply to ethanol blends: NFPA 30, "Flammable and Combustible Liquids Code," and NFPA 30A, "Automotive and Marine Service Station Code." These codes contain information on fueling facilities, storage, and handling requirements for all flammable and combustible liquids. NFPA assigns ethanol fuels (including
E98 and E85) to the same class as gasoline. Copies of these standards can be obtained through the Office of the State Fire Marshal or NFPA. The 2012 edition of the International Code Council 2012 Fire Code has information on the "Code for Motor Fuel Dispensing Facilities and Repair Garages" in the Installation section (Section 304).

The Occupational Safety and Health Administration (OSHA) regulates some fuel dispensing equipment. OSHA regulations applicable to service stations have not been updated in decades and therefore do not specifically address biofuels. OSHA is planning to update these standards and address the changing fuels landscape. OSHA regulation 1910.106 (g)(3)(iv)(b)(1) requires dispensers, breakaways, and nozzles to be listed by a third party for specific fuels. OSHA regulations 1910.106(b)(1)(i)(c) and (c)(2)(ii) require tanks, piping, valves, and fittings other than steel to use sound engineering design for materials used - there is no listing requirement. OSHA regulation 1910.106(b)(1)(iii)(a) covers steel tanks and requires sound engineering and applicable UL listings. An example material safety data sheet for E85 is available on the AFDC website. 16

15. www.ethanolrfa.org/pages/industry-resources-safety

16. Speedway E85. MSDS Solution Center. May 25, 2011. www.afdc.energy.gov/uploads/publication/SSA_MSDS.pdf 


\section{Flexible Fuel Vehicles}

Nearly all gasoline-fueled passenger cars and light-duty trucks sold in the United States in the last 20 years have been designed to operate on E10; EPA has approved E15 for use in conventional gasoline vehicles of model year 2001 and newer. Flexible fuel vehicles (FFVs) feature modifications that allow them to safely and effectively operate on higher-level ethanol blends. FFVs can run on E85, gasoline, or any blend of the two, without adverse effects on fuel system materials, on-board diagnostics (OBD) systems, or driveability. Original equipment manufacturers (OEMs) identify FFVs with a label inside the fuel door that indicates E85 and gasoline capability.

The list of fuel-system components that must be modified for FFVs is extensive. These modifications account for the properties and energy content in ethanol blends. Examples include hoses and other rubber components, such as fuel pump and fuel pressure regulator diaphragms and fuel injector o-rings, to address possible leakage and permeation of fuel and vapor. Modified electrical wiring and connectors are required for submersed components, such as the fuel-level sensor and fuel pump. Increased evaporative emissions carbon canister capacity, a modified fuel tank vapor pressure sensor, and modified engine valve and valve seat materials may also be required. Both metal and plastic fuel tanks must be designed to accommodate E85. For example, traditional terne-plated steel (lead-tin alloy coating) fuel tanks and monolayer high-density polyethylene fuel tanks are not compatible with E85.

FFVs detect the concentration of ethanol in the fuel through the use of either a flexible fuel sensor or a computer calculation based on oxygen sensor information. Many 2006 and later model year FFVs have eliminated the sensor in favor of the computer calculation method. The engine control computer adjusts engine fueling for the oxygen content and reduced energy content of ethanol in order to maintain the proper air/fuel ratio under the various engine operating loads and conditions. The vaporization characteristics of ethanol require modified engine fueling strategies under engine cold-start and warm-up conditions as well.

If E85 is used in a conventional vehicle, fuel system materials and components may be affected over time and lead to leaks. Driveability, performance, and emissions may also be affected, and the OBD system may

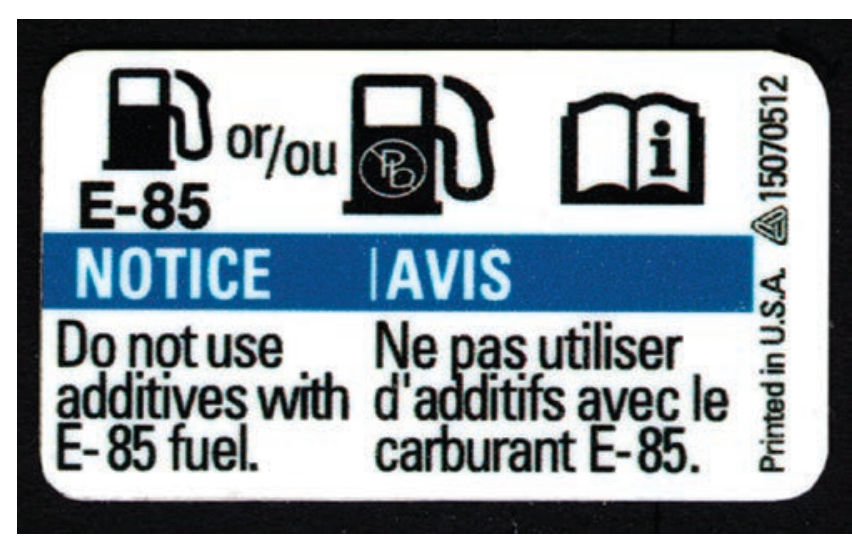

OEMs place labels like these inside FFV fuel doors.

trigger the service engine light and set diagnostic codes related to lean engine operation.

The extent of the necessary modifications throughout the fuel system and electronic engine control system make aftermarket or field modification of existing vehicles complicated and costly. EPA has established rules and guidelines for vehicle conversions for alternative fuel use. Each engine family must be certified separately with EPA, a process that includes filing the necessary paperwork and conducting required emission testing at a laboratory capable of performing EPA testing methods. Comprehensive information is available on EPA's certification procedures for alternative fuel conversions on EPA's website. ${ }^{17}$

In the U.S. marketplace, FFVs are available in dozens of models, from several manufacturers. Many of these vehicles are available at no additional cost compared to conventional gasoline-fueled vehicles, but some FFVs carry a nominal additional charge. For a list of FFVs available from OEMs, visit FuelEconomy.gov or the Alternative Fuels Data Center Light-Duty Vehicle Search. ${ }^{18}$

Federal and state governments have established regulations for the purpose of advancing the use of all forms of alternative transportation fuels. For a list of these programs, visit the Federal and State Laws and Incentives section of the AFDC website at afdc. energy.govllaws.

17. www.epa.gov/otaq/consumer/fuels/altfuels/altfuels.htm

18. www.afdc.energy.gov/vehicles/search/light/ 


\section{Checklist for Installing E85 or Blender Pump Dispensing Equipment or Converting Underground Storage Tanks}

\section{Dispensing Equipment}

Notify your installer to review the applicable codes (generally NFPA 30A or IFC 2012), then contact the local authority having jurisdiction (AHJ), usually the building code office or local fire marshal, to determine whether there are any local code issues that should be addressed.

Notify the nearest fire department (and/or local first responders) that the site will soon be dispensing alcoholblended fuels. Verify that fire extinguishers and other on-site safety equipment (necessary to respond to leaks, spills, fires, etc.) are ethanol compatible.

Use Underwriters Laboratories (UL)-listed equipment (required by OSHA for dispenser, breakaway, and nozzle) or obtain a waiver from the local AHJ:

- Dispenser system (UL 87A); available for both E85 and blender pumps

- Fill hose, dispensing nozzle, swivel, and breakaway

- Emergency shut-off valves

- Pumps

- Leak-detection devices

- All other piping, equipment, and materials must be approved by the manufacturer for its intended use and be compatible with EPA regulations, 40 CFR 280, and applicable guidance.

Use a 5-10-micron alcohol-compatible dispenser filter. Do not use 10-micron gasoline or 30-micron diesel filters.

Do not store or use denatured ethanol or any gasoline/ethanol blend with more than 85 percent ethanol by volume at a retail facility.

Calibrate the dispenser meter at the time of conversion or new installation and two weeks later to verify meter accuracy with E85.

Label the dispenser with all E85 logos, cautionary labels, and trade commission decals. Use nozzle covers stating that E85 is not gasoline or diesel. Add logos for blender pump fuels, and indicate that they are for FFVs only. Consider using hangtags, pump toppers, and other signage to educate your customers. Price sign inserts, curbside signs, and decals are available from industry associations.

Train site operators and emergency response personnel responsible for this location on ethanol fuel safety procedures and the differences relative to gasoline.

\section{Underground Tanks}

Notify your licensed installer (some states do not require installers to have a license) and the state underground storage tank (UST) program of your intent to dispense E85. Print a copy of the statement of compatibility from your tank manufacturer (see Appendix A for tank compatibility and links to letters). 
Notify your UST insurance carrier to determine whether it has additional requirements for E85 fuels.

Obtain an amended insurance certificate showing coverage of E85 storage and dispensing.

In the case of a conversion, clean the tank of all water and sediment. Ensure no water is present, to protect the quality of your ethanol-blended fuels and your customers" vehicles (see API Publication 2015, "Cleaning Petroleum Storage Tanks," and NFPA 326, "Standard for the Safeguarding of Tanks and Containers for Entry, Cleaning, or Repair," 2010 Edition).

Ensure all visible fittings and connections at the top of the tank are tight (no vapors escape, and no water enters).

Ensure the sump and spill containment covers will prevent water from entering the system. Identify the E85 fill port and paint the access cover according to API RP 1637. Make certain transport drivers cannot make fuel deliveries to the wrong fill pipe.

As a precaution to address residual sludge and gum deposits that will be dissolved by ethanol, industry recommends the tank to be filled to $80 \%$ of capacity and kept as full as possible for seven to 10 days. The residual impurities will be more diluted in a larger quantity of E85, reducing the risk of vehicle problems. This practice is also likely to expose any problems related to sludge and gum deposits during the initial inspection period.

Conduct a precision test of the tank system ( 0.1 gallon/hour leak rate) with an automatic tank gauging system within seven days after the tank is filled, to confirm the integrity of the system and that the leak detection equipment is operating properly. Report any fail results as required by the AHJ.

\section{Maintenance}

Check for water regularly. Ensure that no water is contaminating your fueling system. If water is suspected or detected, track down its source and fix the problem immediately. The best way to guard against contamination is to properly clean and maintain the fueling system. Confirm no leaks exist in the tank fill cap and containment reservoir before beginning your E85 operation.

If the product seems to pump slowly, check and replace filters. Persistently clogged filters could indicate moisture or another source of contamination.

If installing a blender pump, ensure that the ethanol content is updated in the control system as the percentage changes according to geography and season. 


\section{Checklist for Dispensing E15}

Contact marketing/branding and state your intention to sell E15.

Contact your insurance company to determine any requirements impacting coverage related to E15 sales.

Adopt the RFA E15 Misfueling Mitigation Plan, as approved by EPA. ${ }^{24}$

Register for the RFG Survey Association's E15 retail survey at www.rfgsa.org.

\section{Dispensing Equipment}

EPA has approved the following dispenser hose configurations for dispensing E15:

- Dedicated E15 hose

- Common E15/E10/E0 hose; this configuration includes additional requirements:

- Minimum 4 gallon purchase (label required); or

- At least one fueling position with a dedicated E10 hose.

Use Underwriters Laboratories (UL)-listed equipment or obtain a waiver from the local AHJ:

- Dispenser retrofit kits are available from Gilbarco, allowing E15 to be sold in existing dispensers. The Encore E25 Retrofit Kit includes a meter and valve assembly that enables easier installation. Wayne retrofit kits are expected in late 2013.

- Purchase and install E25-listed fill hose, dispensing nozzle, swivel, and breakaway (see Appendix D).

- All other piping, equipment, and materials must be approved by the manufacturer for the intended use.

Calibrate the dispenser meter at the time of conversion or new installation and two weeks later to verify meter accuracy with E15.

Label the dispenser with the required EPA E15 label; if E10 and E15 are dispensed from the same hose, add a label stating the four-gallon minimum fueling volume. Consider using hangtags, pump toppers, and other signage to educate your customers. Price sign inserts, curbside signs, and decals are available from industry associations, including the Blend Your Own website (www.byoethanol.com or www.ethanolretailer.com).

Train site operators and emergency response personnel responsible for this location on ethanol fuel safety procedures and the differences relative to gasoline.

\section{Underground Tanks}

Notify your licensed installer (some states do not require installers to have a license) and the state underground storage tank (UST) program of your intent to dispense E15. Print a copy of the statement of compatibility from your tank manufacturer (see Appendix E to determine compatibility of tanks and find links to letters).

Obtain an amended insurance certificate showing coverage of E15 storage and dispensing.

If storing E85-blended E15, refer to the Checklist for Installing E85 (page 19).

24. "Renewable Fuels Association Model E15 Misfueling Mitigation Plan.” EPA OTAQ. March 2, 2012. 


\section{Information Resources}

\section{General}

Alternative Fuels Data Center afdc.energy.gov

National Renewable Energy Laboratory www.nrel.gov

EPA Office of Transportation and Air Quality www.epa.gov/otaqlfuels/alternative-renewablefuels

California Air Resources Board Fuels Programs www.arb.ca.govlfuelslfuels.htm

Blend Your Own www.byoethanol.com

Ethanol Retailer www.ethanolretailer.com

Renewable Fuels Association www.ethanolrfa.org

Governors' Biofuels Coalition www.governorsbiofuelscoalition.org

National Corn Growers Association www.ncga.com

Growth Energy www.growthenergy.org

American Coalition for Ethanol www.ethanol.org

Clean Fuels Development Coalition www.cleanfuelsdc.org

\section{Ethanol Fuel Codes and Safety}

Occupational Safety \& Health Administration www.osha.gov

National Fire Protection Association www.nfpa.org

International Association of Fire Chiefs www.iafc.org

Underwriters Laboratories www.ul.com

\section{Standards}

ASTM International www.astm.org

Underwriters Laboratories www.ul.com
U.S. Department of Transportation Pipeline and Hazardous Materials Safety Administration www.phmsa.dot.gov

SAE International www.sae.org

EPA Office of Transportation and Air Quality www.epa.govlotaqlfuels/alternative-renewablefuels

California Air Resources Board Fuels Programs www.arb.ca.govlfuelslfuels.htm

Alliance of Automobile Manufacturers www.autoalliance.org

\section{Equipment}

Petroleum Equipment Institute Alternative Fuels Equipment Compatibility Guide resource.pei.orglaltfuels/byfuel.asp

Fiberglass Tank and Pipe Institute www.fiberglasstankandpipe.com

Steel Tank Institute www.steeltank.com

\section{Flexible Fuel Vehicles}

Alternative Fuels Data Center www.afdc.energy.gov/vehicles/flexible_fuel.html

Alliance of Automobile Manufacturers www.autoalliance.org

\section{Emissions}

National Renewable Energy Laboratory www.nrel.gov

Coordinating Research Council www.crcao.com

EPA Office of Transportation and Air Quality www.epa.gov/otaqlfuels/alternative-renewablefuels

California Air Resources Board Fuels Programs www.arb.ca.govlfuels/fuels.htm

Alliance of Automobile Manufacturers www.autoalliance.org

SAE International www.sae.org 


\section{Appendix A: EPA Biofuels Guidance Manufacturer Statements of Compatibility}

\section{Table A1. Tank Manufacturer Compatibility with Ethanol Blends}

Manufacturer

Fiberglass $^{1}$

Containment Solutions

\begin{tabular}{|l|l|}
\hline \multirow{3}{*}{ Owens Corning } & Single Wall Tanks \\
\cline { 2 - 3 } & Double Wall Tanks \\
\hline \multirow{3}{*}{ Xerxes } & Single Wall Tanks \\
& \\
\cline { 2 - 3 } & \\
& Double Wall Tanks \\
& \\
\hline
\end{tabular}

\section{Compatibility Statement}

Tanks manufactured after January 1, 1995 are all compatible with ethanol blends up to $100 \%$ (E100) (UL Listed)

Tanks manufactured between 1965 and 1994 are approved to store up to $10 \%$ ethanol (E10)

Tanks manufactured between 1965 and July 1, 1990 are approved to store up to $10 \%$ ethanol (E10)

Tanks manufactured between July 2, 1990 and December 31, 1994 were warrantied to store any ethanol blend

Tanks manufactured prior to 1981 are not compatible with ethanol blends

Tanks manufactured from February 1981 through June 2005 are designed for the storage of ethanol fuel up to a $10 \%$ blend (E10)

Tanks manufactured from July 2005 to date are designed for the storage of ethanol fuel blends up to $100 \%$ (E100) (UL Listed)

Tanks manufactured prior to April 1990 were designed for the storage of ethanol fuel up to a $10 \%$ blend (E10)

Tanks manufactured from April 1990 to date are designed for the storage of ethanol fuel blends up to 100\% (E100) (UL Listed)

\section{Steel ${ }^{2}$}

Acterra Group Inc.

Caribbean Tank Technologies Inc.

Eaton Sales \& Service LLC

General Industries

Greer Steel Inc.

Hall Tank Co.

Hamilton Tanks

Highland Tank

J.L. Houston Co.

Kennedy Tank and Manufacturing Co. Inc.

Lancaster Tanks and Steel Products
Compatible with all blends up to 100\% (E100)

Compatible with all blends up to 100\% (E100)

Compatible with all blends up to 100\% (E100)

Compatible with all blends up to 100\% (E100)

Compatible with all blends up to 100\% (E100)

Compatible with all blends up to 100\% (E100)

Compatible with all blends up to 100\% (E100)

Compatible with all blends up to 100\% (E100)

Compatible with all blends up to 100\% (E100)

Compatible with all blends up to 100\% (E100)

Compatible with all blends up to 100\% (E100) 


\section{Appendix A: EPA Biofuels Guidance Manufacturer Statements of Compatibility}

\begin{tabular}{|c|c|}
\hline Manufacturer & Compatibility Statement \\
\hline \multicolumn{2}{|l|}{ Steel2 ${ }^{2}$} \\
\hline Lannon Tank Corp. & Compatible with all blends up to $100 \%$ (E100) \\
\hline Mass Tank Sales Corp. & Compatible with all blends up to $100 \%$ (E100) \\
\hline Metal Products Company & Compatible with all blends up to $100 \%$ (E100) \\
\hline Mid-South Steel Products Inc. & Compatible with all blends up to $100 \%$ (E100) \\
\hline Modern Welding Company & Compatible with all blends up to $100 \%$ (E100) \\
\hline Newberry Tanks \& Equipment LLC & Compatible with all blends up to $100 \%$ (E100) \\
\hline Plasteel ${ }^{1}$ & Compatible with all blends up to $100 \%$ (E100) \\
\hline Service Welding \& Machine Company & Compatible with all blends up to $100 \%$ (E100) \\
\hline Southern Tank \& Manufacturing Co. Inc. & Compatible with all blends up to $100 \%$ (E100) \\
\hline Stanwade Metal Products & Compatible with all blends up to $100 \%$ (E100) \\
\hline Talleres Industriales Potosinos, S.A. de C.V. & Compatible with all blends up to $100 \%$ (E100) \\
\hline Tanques Antillanos C. x A. & Compatible with all blends up to $100 \%$ (E100) \\
\hline Watco Tanks Inc. & Compatible with all blends up to $100 \%$ (E100) \\
\hline We-Mac Manufacturing Company & Compatible with all blends up to $100 \%$ (E100) \\
\hline
\end{tabular}

Letters stating compability:

1. PEI www.pei.org/PublicationsResources/ComplianceFunding/USTComponentCompatibilityLibrary/tabid/882/Default.aspx

2. STI www.steeltank.com/Publications/E85BioDieselandAlternativeFue/s/ManufacturerStatementsofCompatibility/tabid/468/Default.aspx 


\section{Appendix A: EPA Biofuels Guidance Manufacturer Statements of Compatibility}

\begin{tabular}{|c|c|c|c|}
\hline Manufacturer & Product & Model & $\begin{array}{l}\text { Ethanol } \\
\text { Compatibility }\end{array}$ \\
\hline Bravo Systems & Fiberglass Fittings & $\begin{array}{l}\text { Series F, FF, FPE, FR, F Retrofit- } \\
\text { S, RPE Retrofit-Si, F BLR, F } \\
\text { D-BLR-S, TBF }\end{array}$ & E0-E100 \\
\hline Bravo Systems & Spill Buckets & $B 3 X X$ & E0-E100 \\
\hline Bravo Systems & Tank Sumps \& Covers & $\mathrm{B} 4 \mathrm{XX}$ & E0-E100 \\
\hline Bravo Systems & $\begin{array}{l}\text { Transition Sumps (planter, } \\
\text { walkover, } \mathrm{H}-20 \text { rated) }\end{array}$ & B5XX, B6XX, B7XX, B8XX & E0-E100 \\
\hline Bravo Systems & Transition Sumps & B8XX & E0-E100 \\
\hline Bravo Systems & $\begin{array}{l}\text { Under Dispenser Contain- } \\
\text { ment Sumps }\end{array}$ & B7XXX, B8XXX, B9XXX & E0-E100 \\
\hline Brugg & Pipes & $\begin{array}{l}\text { FLEXWELL-HL, SECON-X, } \\
\text { NIROFLEX, LPG }\end{array}$ & E0-E100 \\
\hline $\begin{array}{l}\text { KPS Petrol } \\
\text { Pipe Systems }\end{array}$ & $\begin{array}{l}\text { Pipes and Associated } \\
\text { Products }\end{array}$ & $\begin{array}{l}\text { All single- and double-wall } \\
\text { plastic pipes, flexible connec- } \\
\text { tors, plastic fittings, gaskets, } \\
\text { couplings, entry boots, contain- } \\
\text { ment sumps, leak-detector units } \\
\text { for filling and refueling }\end{array}$ & E0-E100 \\
\hline Morrison Bros. & Expansion Relief Valve & 076DI, 078DI & E0-E85 \\
\hline Morrison Bros. & Frost Proof Drain Valve & $128 \mathrm{DIS}$ & E0-E85 \\
\hline Morrison Bros. & Double Outlet Vent & 155 & E0-E85 \\
\hline Morrison Bros. & Double Tap Bushing & 184 & E0-E85 \\
\hline Morrison Bros. & Anodized Farm Nozzle & $200 S$ & E0-E85 \\
\hline Morrison Bros. & Emergency Vents & 244 & E0-E85 \\
\hline Morrison Bros. & Swing Check Valves & 246ADI, 246DRF & E0-E85 \\
\hline Morrison Bros. & $\begin{array}{l}\text { Internal Emergency } \\
\text { Valves }\end{array}$ & 272DI, 72HDI & E0-E85 \\
\hline Morrison Bros. & Line Strainers with Teflon & 285 & E0-E85 \\
\hline Morrison Bros. & Caps & $305 C$ & E0-E85 \\
\hline Morrison Bros. & $\begin{array}{l}\text { Tank Monitor Adaptor } \\
\text { and Cap Kits }\end{array}$ & $305 X P A$ & E0-E85 \\
\hline Morrison Bros. & Float Vent Valves & 317 & E0-E85 \\
\hline
\end{tabular}




\section{Appendix A: EPA Biofuels Guidance Manufacturer Statements of Compatibility}

\begin{tabular}{|c|c|c|c|}
\hline Manufacturer & Product & Model & $\begin{array}{l}\text { Ethanol } \\
\text { Compatibility }\end{array}$ \\
\hline Morrison Bros. & $\begin{array}{l}\text { Vapor Recovery Adaptor } \\
\text { with Viton }\end{array}$ & 323 & E0-E85 \\
\hline Morrison Bros. & Vapor Recovery Caps & $323 C$ & E0-E85 \\
\hline Morrison Bros. & $\begin{array}{l}\text { External Emergency } \\
\text { Valves }\end{array}$ & 346DI, 346FDI, 346SS, 346FSS & E0-E85 \\
\hline Morrison Bros. & Updraft Vents & 354 & E0-E85 \\
\hline Morrison Bros. & Flame Arrester & $351 S$ & E0-E85 \\
\hline Morrison Bros. & Anodized Drop Tubes & $419 A$ & E0-E85 \\
\hline Morrison Bros. & Spill Containers & $515 / 516 / 517 / 518$ & E0-E85 \\
\hline Morrison Bros. & Anodized Diffusers & 539то, 539тС & E0-E85 \\
\hline Morrison Bros. & Pressure Vacuum Vents & 548 & E0-E85 \\
\hline Morrison Bros. & Extractors & $560 / 561 / 562 / 563$ & E0-E85 \\
\hline Morrison Bros. & Ball Valves & 691BSS & E0-E85 \\
\hline Morrison Bros. & $\begin{array}{l}\text { Solenoid Valves ( } 3 \text { " Must } \\
\text { Be All Teflon Version) }\end{array}$ & 710ss & E0-E85 \\
\hline Morrison Bros. & Pressure Vacuum Vents & 748,749 & E0-E85 \\
\hline Morrison Bros. & Clock Gauges & 818 & E0-E85 \\
\hline Morrison Bros. & Anti-Syphon Valve & 912 & E0-E85 \\
\hline Morrison Bros. & Clock Gauge with Alarm & 918 & E0-E85 \\
\hline Morrison Bros. & Overfill Alarm & 918TCP & EO-E85 \\
\hline Morrison Bros. & $\begin{array}{l}\text { Combination Vent/Over- } \\
\text { fill Alarm }\end{array}$ & 922 & E0-E85 \\
\hline Morrison Bros. & Dry Disconnect Adaptor & 927 & E0-E85 \\
\hline Morrison Bros. & In-Line Check Valve & 958 & E0-E85 \\
\hline Morrison Bros. & Overfill Prevention Valve & 9095A-AV, 9095SS & E0-E85 \\
\hline $\begin{array}{l}\text { National Environmental } \\
\text { Fiberglass }\end{array}$ & Dispenser Sumps & All & E0-E100 \\
\hline $\begin{array}{l}\text { National Environmental } \\
\text { Fiberglass }\end{array}$ & Tank Collars & All & E0-E100 \\
\hline
\end{tabular}




\section{Appendix A: EPA Biofuels Guidance Manufacturer Statements of Compatibility}

\begin{tabular}{|c|c|c|c|}
\hline Manufacturer & Product & Model & $\begin{array}{l}\text { Ethanol } \\
\text { Compatibility }\end{array}$ \\
\hline $\begin{array}{l}\text { National Environmental } \\
\text { Fiberglass }\end{array}$ & Tank Sumps and Collars & All & E0-E100 \\
\hline $\begin{array}{l}\text { National Environmental } \\
\text { Fiberglass }\end{array}$ & Transition Sumps & All & E0-E100 \\
\hline $\begin{array}{l}\text { National Environmental } \\
\text { Fiberglass }\end{array}$ & $\begin{array}{l}\text { Single Wall Tank and } \\
\text { Transition Sumps }\end{array}$ & All & E0-E100 \\
\hline $\begin{array}{l}\text { National Environmental } \\
\text { Fiberglass }\end{array}$ & $\begin{array}{l}\text { Double Wall Tank and } \\
\text { Transition Sumps }\end{array}$ & All & E0-E100 \\
\hline $\begin{array}{l}\text { NOV Fiberglass } \\
\text { Systems }\end{array}$ & Pipe & $\begin{array}{l}\text { Red Thread IIA (UL listed for } \\
\text { E0-E100) }\end{array}$ & E0-E100 (UL Listed) \\
\hline NUPI Americas & Pipe and Fittings & Smartflex & E0-E100 (UL Listed) \\
\hline Omegaflex & $\begin{array}{l}\text { Pipe, Fittings, and } \\
\text { Accessories }\end{array}$ & $\begin{array}{l}\text { DoubleTrac (brass and stainless } \\
\text { steel fittings) }\end{array}$ & E0-E100 (UL Listed) \\
\hline $\begin{array}{l}\text { Vaporless } \\
\text { Manufacturing Inc. }\end{array}$ & Leak Detectors & $\begin{array}{l}99 \text { LD-2000/2200/3000 (must } \\
\text { use stainless steel tubing and } \\
\text { fittings) }\end{array}$ & E0-E100 \\
\hline $\begin{array}{l}\text { Vaporless } \\
\text { Manufacturing Inc. }\end{array}$ & Overfill Prevention Valve & $\begin{array}{l}\text { OFP- } 2 / 3 \text { (must use stainless } \\
\text { steel tubing and fittings) }\end{array}$ & E0-E100 \\
\hline Western Fiberglass & Co-Flex Piping & All & E0-E100 \\
\hline Western Fiberglass & Cuff Fittings & All & E0-E100 \\
\hline Western Fiberglass & $\begin{array}{l}\text { Sumps (Tank, Dispenser, } \\
\text { Transition, Vapor/Vent) }\end{array}$ & All & E0-E100 \\
\hline Western Fiberglass & $\begin{array}{l}\text { Co-Flow Hydrostatic } \\
\text { Monitoring Systems }\end{array}$ & All & E0-E100 \\
\hline
\end{tabular}

All letters stating compatibility are available from Petroleum Equipment Institute's website: www.pei.org/PublicationsResources/ ComplianceFunding/USTComponentCompatibilityLibrary/tabid/882/Default.aspx 


\section{Appendix B: Various Specifications for Fuel Ethanol, E85, and Denaturant}

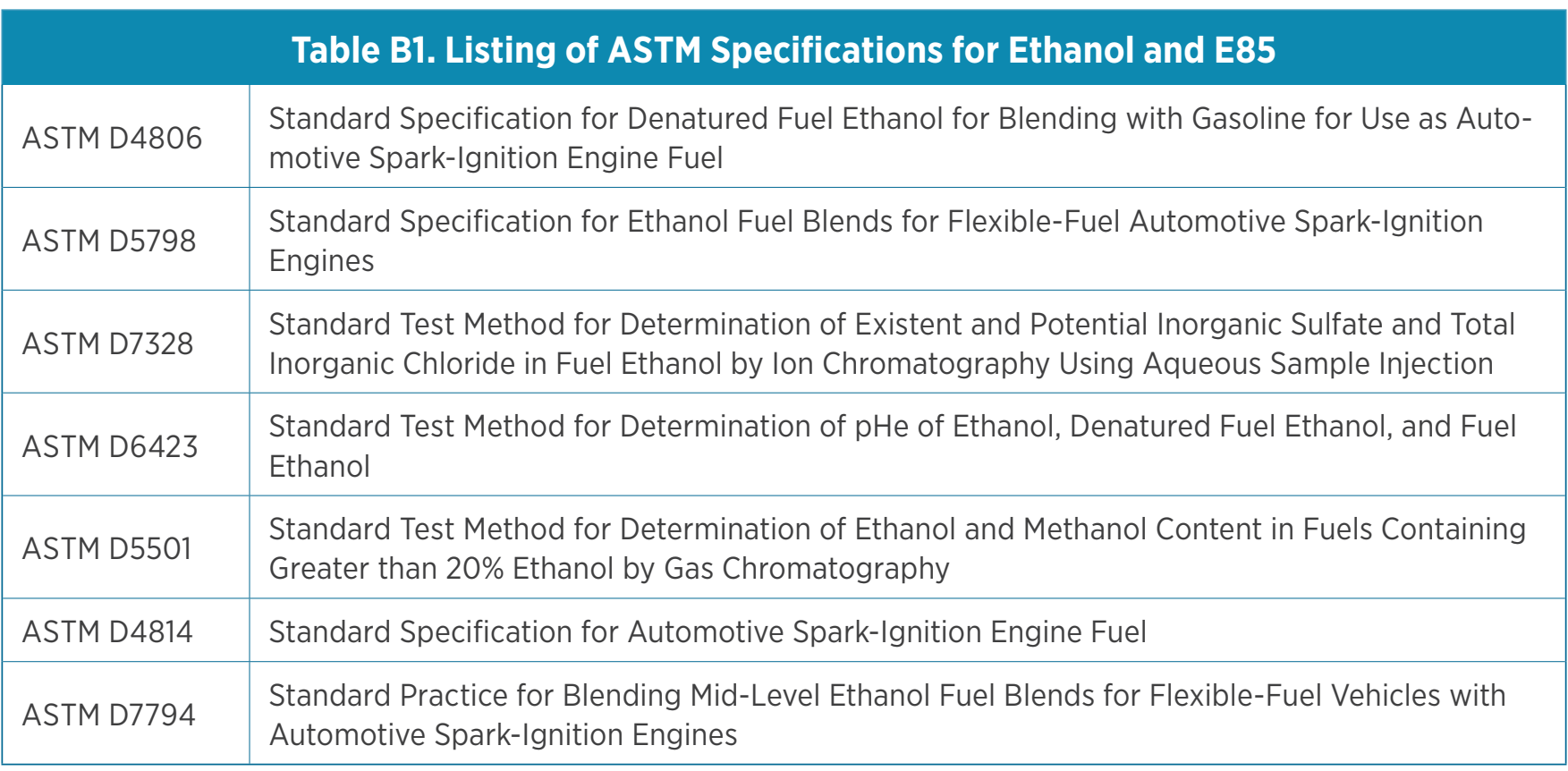

ASTM D4806 standard sets guidelines for purity and other important properties for ethanol that is to be blended into gasoline. Major ethanol producers often establish additional guidelines that may exceed ASTM requirements. In addition, RFA has established specifications and quality standards for ethanol manufactured by its member companies (RFA Recommended Practice 911201). RFA Publication No. 96050117, "Fuel Ethanol: Industry Guidelines, Specifications and Procedures," also contains helpful information on fuel ethanol specifications.

Table B2. ASTM D4806 Standard Specification for Denatured Fuel Ethanol for Blending with Gasoline for Use as Automotive Spark-Ignition Engine Fuel

\begin{tabular}{|c|c|c|}
\hline Property & Specification & ASTM Test Method \\
\hline Ethanol, volume \%, minimum & 92.1 & D5501 \\
\hline Methanol, volume $\%$, maximum & 0.5 & \\
\hline Solvent-washed gum, mg/100 mL, maximum & 5.0 & D381 \\
\hline Sulfur, mass ppm, maximum & 30 & D6428, D5453, D2622 \\
\hline Water content, volume \%, maximum & 1.0 & E203 \\
\hline Sulfate, mass ppm, maximum & 4 & D7318, D7319, D7328 \\
\hline $\begin{array}{l}\text { Denaturant content, volume } \% \text {, minimum } \\
\text { volume } \% \text {, maximum }\end{array}$ & $\begin{array}{l}1.96 \\
5.0\end{array}$ & \\
\hline Inorganic chloride content, mass ppm (mg/L), maximum & 10. (8) & D512 \\
\hline Copper content, mg/kg, maximum & 0.1 & D1688 \\
\hline Acidity (as acetic acid, $\mathrm{CH}_{3} \mathrm{COOH}$ ), mass $\%$ (mg/L), maximum & $0.007(56)$ & D1613 \\
\hline $\mathrm{pHe}$ & $6.5-9.0$ & D6423 \\
\hline Appearance & \multicolumn{2}{|c|}{$\begin{array}{l}\text { Visibly free of suspended or precipitated con- } \\
\text { taminants (clear and bright) }\end{array}$} \\
\hline
\end{tabular}

Source: ASTM International Standards Worldwide, 100 Barr Harbor Dr., P.O. Box C700, West Conshohocken, PA, 19428, www.astm.org 


\section{Appendix B: Various Specifications for Fuel Ethanol, E85, and Denaturant}

\begin{tabular}{|c|c|c|}
\hline Property & $\begin{array}{l}\text { Specification } \\
\text { Limit }\end{array}$ & ASTM Test Method \\
\hline Sulfur, ppm, maximum & 10 & D5453-93 \\
\hline Benzene, volume $\%$, maximum & 0.06 & $\begin{array}{l}\text { D7576-10 test results of a sample of the denaturant multiplied } \\
\text { by } 0.0500 \text { or the denaturant fraction, whichever is less }\end{array}$ \\
\hline Olefins, volume $\%$, maximum & 0.5 & $\begin{array}{l}\text { D7347-07e1 test results of a sample of the denaturant mul- } \\
\text { tipled by } 0.0500 \text { or the denaturant fraction, whichever is less }\end{array}$ \\
\hline Aromatics, volume $\%$, maximum & 1.7 & $\begin{array}{l}\text { D7576-10 test results of a sample of the denaturant multiplied } \\
\text { by } 0.0500 \text { or the denaturant fraction, whichever is less }\end{array}$ \\
\hline
\end{tabular}

California has promulgated additional specifications for denatured ethanol and the denaturant hydrocarbon that apply to ASTM D4806.

\begin{tabular}{|l|c|c|}
\hline \multicolumn{2}{|c|}{ Table B4. California Denaturant Standards } \\
\hline \multicolumn{1}{|c|}{ Property } & Specification Limit & ASTM Test Method \\
\hline Benzene, volume \%, maximum & 1.1 & D5580-02 (2007) \\
\hline Olefins, volume \%, maximum & 10 & D6550-10 \\
\hline Aromatics, volume \%, maximum & 35 & D5580-02 (2007) \\
\hline
\end{tabular}

\section{Table B5. Natural Gasoline Specifications and Test Methods}

These specifications state the required properties of natural gasoline. Natural gasoline is a mixture of liquid hydrocarbons extracted from natural gas, composed principally of pentanes and heavier hydrocarbons, although varying amounts of butanes may be included, depending on the commercial grade.

Natural gasoline is defined further for commercial purposes by the following:

\begin{tabular}{|l|c|c|}
\hline Product Characteristic & Specification & Test Method \\
\hline Reid Vapor Pressure & $10-34$ pounds & ASTM D-323-82 \\
\hline Percentage Evaporated at $140^{\circ} \mathrm{F}$ & $25-85$ & ASTM D-216-77 (82) \\
\hline Percentage Evaporated at $275^{\circ} \mathrm{F}$ & Not less than 90 & ASTM D-216-77 (82) \\
\hline End Point & Not more than $375^{\circ} \mathrm{F}$ & ASTM D-216-77 (82) \\
\hline Corrosion & Not more than classification 1 & ASTM D-130-80 (modified) \\
\hline Color & Not less than plus 25 (Saybolt) & ASTM D-156-82 \\
\hline Reactive Sulfur & Negative, "sweet" & GPA 1138 \\
\hline
\end{tabular}

Source: Gas Processors Association, www.gasprocessors.com 


\section{Appendix B: Various Specifications for Fuel Ethanol, E85, and Denaturant}

\section{Table B6. Specifications for Fuel Ethanol Denaturants}

Under 27 CFR 19.1005(b), the following materials are approved to render spirits unfit for beverage use and thus acceptable for withdrawal from alcohol fuel plants as fuel alcohol.

1. The materials listed in 27 CFR 19.10 05(c), in the quantities specified there.

2. The following additional materials, in the following quantities, corresponding to the following specifications:

\begin{tabular}{|c|c|c|c|}
\hline Material & $\begin{array}{l}\text { Quantity Added to } \\
100 \text { Gallons of } \\
\text { Distilled Spirits }\end{array}$ & \multicolumn{2}{|l|}{ Specifications } \\
\hline $\begin{array}{l}\text { Natural } \\
\text { gasoline }\end{array}$ & 2 gallons or more & \multicolumn{2}{|c|}{$\begin{array}{l}\text { 1. Natural gasoline (drip gas) is a mixture of butane, pentane, and hexane } \\
\text { hydrocarbons extracted from natural gas. } \\
\text { 2. Distillation range: No more than } 10 \% \text { of the sample may distill below } \\
97^{\circ} \mathrm{F} \text {.; at least } 50 \% \text { shall distill at or below } 156^{\circ} \mathrm{F} \text {.; and at least } 90 \% \\
\text { shall distill at or below } 209^{\circ} \mathrm{F} \text {. }\end{array}$} \\
\hline $\begin{array}{l}\text { Ethyl tertiary- } \\
\text { butyl ether } \\
\text { (ETBE) }\end{array}$ & 2 gallons or more & \multicolumn{2}{|l|}{$\mathrm{N} / \mathrm{A}$} \\
\hline Raffinate & 2 gallons or more & $\begin{array}{l}\text { 1. Octane }(R+M / 2): 66-70 \\
\text { 2. Distillation, in degrees } F \text { : } \\
\text { - } 10 \%: 120-150 \\
\text { - } 50 \%: 144-180\end{array}$ & $\begin{array}{l}\text { - } 90 \%: 168-200 \\
\text { - End point: } 216-285 \\
\text { 3. API gravity: } 76-82 \\
\text { 4. Reid vapor pressure: } 5-11\end{array}$ \\
\hline Naphtha & 2 gallons or more & $\begin{array}{l}\text { 1. API gravity } \\
\text { @ 60/60 degrees F: 64-70 } \\
\text { 2. Lb/gal: } 5.845-6.025 \\
\text { 3. Density: .7022-.7238 } \\
\text { 4. Reid vapor pressure: } \\
\text { 8 P.S.I.A. max. } \\
\text { 5. Copper corrosion: } 17 . \\
\text { Saybolt Color: } 28 \text { Min. }\end{array}$ & $\begin{array}{l}\text { 6. Distillation, in degrees F: } \\
\text { - I.B.P.: } 85 \text { max. } \\
\text { - } 10 \%: 130 \text { max. } \\
\text { - 50\%: } 250 \text { max. } \\
\text { - } 90 \%: 340 \text { max. } \\
\text { - End point: } 380\end{array}$ \\
\hline Straight Run & 2 galloncor moro & \multicolumn{2}{|c|}{$\begin{array}{l}\text { 1. Straight run gasoline is a mixture consisting predominantly (greater } \\
\text { than } 60 \% \text { by volume) of C4, C5, C6, C7 and/or C } 8 \text { hydrocarbons, and } \\
\text { is either (1) a petroleum distillate coming straight from an atmospheric } \\
\text { distillation unit without being cracked or reformed or (2) a condensate } \\
\text { coming directly from an oil/gas recovery operation. }\end{array}$} \\
\hline Gasoline & & $\begin{array}{l}\text { 2. API gravity: } 72^{\circ} \text { min., } 85^{\circ} \text { max. } \\
\text { 3. Reid vapor pressure: } 15 \text { psi max. } \\
\text { 4. Sulfur: } 120 \text { ppm max. } \\
\text { 5. Benzene: } 1.1 \% \text { by volume max. }\end{array}$ & $\begin{array}{l}\text { 6. Distillation, in degrees } \mathrm{F} \text { : } \\
\text { - } 10 \%: 97 \text { min., } 158 \text { max. } \\
\text { - } 50 \%: 250 \text { max. } \\
\text { - Final boiling point: } 437^{\circ} \mathrm{F} \text { max. }\end{array}$ \\
\hline Toluene & 5 gallons or more & \multicolumn{2}{|l|}{ See 27 CFR 21.132} \\
\hline
\end{tabular}

Source: U.S. Department of the Treasury Alcohol and Tobacco Tax and Trade Bureau, www.ttb.gov/pdf/authorized_denaturants_fuel_alcohol.pdf 
Appendix C: Seasonal and Geographical Volatility Classes for E85 (ASTM D5798)

\begin{tabular}{|c|c|c|c|c|c|c|c|c|c|c|c|c|}
\hline \multirow[t]{2}{*}{ State and Fuel-Marketing Region } & \multicolumn{12}{|c|}{ Volatility Class by Month } \\
\hline & Jan & Feb & Mar & April & May & June & July & Aug & Sept & Oct & Nov & Dec \\
\hline Alabama & 2 & 2 & 2 & 2 & $2 / 1$ & 1 & 1 & 1 & 1 & $1 / 2$ & 2 & 2 \\
\hline Alaska - Southern Region & 4 & 4 & 4 & $4 / 3$ & $3 / 2$ & $2 / 1$ & 1 & $1 / 2$ & $2 / 3$ & $3 / 4$ & 4 & 4 \\
\hline South Mainland & 4 & 4 & 4 & 4 & $4 / 2$ & $2 / 1$ & $1 / 2$ & 2 & $2 / 4$ & 4 & 4 & 4 \\
\hline Arizona - North of $34^{\circ}$ & 3 & 3 & 3 & $3 / 2$ & 2 & $2 / 1$ & 1 & 1 & $1 / 2$ & $2 / 3$ & 3 & 3 \\
\hline South of $34^{\circ}$ & 2 & 2 & 2 & $2 / 1$ & 1 & 1 & 1 & 1 & 1 & $1 / 2$ & 2 & 2 \\
\hline Arkansas & 3 & 3 & $3 / 2$ & $2 / 1$ & 1 & 1 & 1 & 1 & $1 / 2$ & 2 & $2 / 3$ & 3 \\
\hline California - North Coast & 2 & 2 & 2 & 2 & 2 & 1 & 1 & 1 & 1 & $1 / 2$ & 2 & 2 \\
\hline South Coast & 2 & 2 & 2 & $2 / 1$ & 1 & 1 & 1 & 1 & 1 & $1 / 2$ & 2 & 2 \\
\hline Southeast & 2 & 2 & $2 / 1$ & 2 & 1 & 1 & 1 & 1 & 1 & 1 & $1 / 2$ & 2 \\
\hline Interior & 2 & 2 & 2 & $2 / 1$ & 1 & 1 & 1 & 1 & 1 & $1 / 2$ & 2 & 2 \\
\hline Colorado - East of $105^{\circ}$ longitude & 4 & $4 / 3$ & 3 & $3 / 2$ & 2 & $2 / 1$ & 1 & 1 & $1 / 2$ & $2 / 3$ & 3 & $3 / 4$ \\
\hline West of $105^{\circ}$ longitude & 4 & 4 & $4 / 3$ & 3 & $3 / 2$ & 2 & $2 / 1$ & $1 / 2$ & $2 / 3$ & $3 / 4$ & 4 & 4 \\
\hline Connecticut & 4 & 4 & $4 / 3$ & $3 / 2$ & 2 & $2 / 1$ & 1 & 1 & $1 / 2$ & 2 & $2 / 3$ & $3 / 4$ \\
\hline Delaware & 3 & 3 & $3 / 2$ & 2 & $2 / 1$ & 1 & 1 & 1 & $1 / 2$ & 2 & $2 / 3$ & 4 \\
\hline District of Columbia & 3 & 3 & $3 / 2$ & 2 & $2 / 1$ & 1 & 1 & 1 & $1 / 2$ & 2 & $2 / 3$ & 3 \\
\hline Florida - North of $29^{\circ}$ latitude & 2 & 2 & 2 & $2 / 1$ & 1 & 1 & 1 & 1 & 1 & $1 / 2$ & 2 & 2 \\
\hline South of $29^{\circ}$ latitude & 2 & $2 / 1$ & 1 & 1 & 1 & 1 & 1 & 1 & 1 & 1 & $1 / 2$ & 2 \\
\hline Georgia & 3 & $3 / 2$ & 2 & $2 / 1$ & 1 & 1 & 1 & 1 & 1 & $1 / 2$ & 2 & $2 / 3$ \\
\hline Hawaii & 1 & 1 & 1 & 1 & 1 & 1 & 1 & 1 & 1 & 1 & 1 & 1 \\
\hline Idaho & 4 & 4 & $4 / 3$ & $3 / 2$ & 2 & 2 & $2 / 1$ & $1 / 2$ & 2 & $2 / 3$ & $3 / 4$ & 4 \\
\hline Illinois - North of $40^{\circ}$ latitude & 4 & 4 & $4 / 3$ & $3 / 2$ & 2 & $2 / 1$ & 1 & 1 & $1 / 2$ & $2 / 3$ & $3 / 4$ & 4 \\
\hline South of $40^{\circ}$ latitude & 4 & $4 / 3$ & 3 & $3 / 2$ & $2 / 1$ & 1 & 1 & 1 & $1 / 2$ & $2 / 3$ & $3 / 4$ & 4 \\
\hline Indiana & 4 & 4 & $4 / 3$ & $3 / 2$ & $2 / 1$ & 1 & 1 & 1 & $1 / 2$ & $2 / 3$ & $3 / 4$ & 4 \\
\hline lowa & 4 & 4 & 4 & $4 / 2$ & 2 & $2 / 1$ & 1 & 1 & $1 / 2$ & $2 / 3$ & $3 / 4$ & 4 \\
\hline Kansas & 4 & $4 / 3$ & 3 & $3 / 2$ & 2 & $2 / 1$ & 1 & 1 & $1 / 2$ & $2 / 3$ & $3 / 4$ & 4 \\
\hline Kentucky & 3 & 3 & $3 / 2$ & 2 & $2 / 1$ & 1 & 1 & 1 & $1 / 2$ & 2 & $2 / 3$ & 3 \\
\hline Louisiana & 2 & 2 & 2 & $2 / 1$ & 1 & 1 & 1 & 1 & 1 & $1 / 2$ & 2 & 2 \\
\hline Maine & 4 & 4 & 4 & $4 / 2$ & 2 & $2 / 1$ & 1 & $1 / 2$ & 2 & $2 / 3$ & $3 / 4$ & 4 \\
\hline Maryland & 3 & 3 & $3 / 2$ & 2 & $2 / 1$ & 1 & 1 & 1 & $1 / 2$ & 2 & $2 / 3$ & 3 \\
\hline Massachusetts & 4 & 4 & $4 / 3$ & $3 / 2$ & 2 & $2 / 1$ & 1 & 1 & $1 / 2$ & 2 & $2 / 4$ & 4 \\
\hline Michigan - Lower & 4 & 4 & $4 / 3$ & $3 / 2$ & 2 & $2 / 1$ & 1 & $1 / 2$ & 2 & $2 / 3$ & $3 / 4$ & 4 \\
\hline Upper & 4 & 4 & 4 & $4 / 3$ & $3 / 2$ & $2 / 1$ & 1 & $1 / 2$ & 2 & $2 / 3$ & $3 / 4$ & 4 \\
\hline Minnesota & 4 & 4 & 4 & $4 / 3$ & $3 / 2$ & $2 / 1$ & 1 & $1 / 2$ & 2 & $2 / 4$ & 4 & 4 \\
\hline
\end{tabular}

Table $\mathrm{Cl}$ continued on next page. 


\section{Appendix C: Seasonal and Geographical Volatility Classes for E85 (ASTM D5798)}

Table C1 (continued). Seasonal and Geographical Volatility Classes for 685 (ASTM D5798)

\begin{tabular}{|c|c|c|c|c|c|c|c|c|c|c|c|c|}
\hline \multirow[t]{2}{*}{ State and Fuel-Marketing Region } & \multicolumn{12}{|c|}{ Volatility Class by Month } \\
\hline & Jan & Feb & Mar & April & May & June & July & Aug & Sept & Oct & Nov & Dec \\
\hline Mississippi & 2 & 2 & 2 & $2 / 1$ & 1 & 1 & 1 & 1 & 1 & $1 / 2$ & 2 & 2 \\
\hline Missouri & 4 & $4 / 3$ & 3 & $3 / 2$ & $2 / 1$ & 1 & 1 & 1 & $1 / 2$ & $2 / 3$ & 3 & 3 \\
\hline Montana & 4 & 4 & 4 & $4 / 3$ & $3 / 2$ & 2 & $2 / 1$ & $1 / 2$ & $2 / 3$ & $3 / 4$ & 4 & 4 \\
\hline Nebraska & 4 & 4 & $4 / 3$ & $3 / 2$ & 2 & $2 / 1$ & 1 & $1 / 2$ & 2 & $2 / 3$ & $3 / 4$ & 4 \\
\hline Nevada - North of $38^{\circ}$ latitude & 4 & 4 & $4 / 3$ & $3 / 2$ & 2 & 2 & $2 / 1$ & $1 / 2$ & 2 & $2 / 3$ & $3 / 4$ & 4 \\
\hline South of $38^{\circ}$ latitude & 3 & 3 & $3 / 2$ & 2 & $2 / 1$ & 1 & 1 & 1 & $1 / 2$ & 2 & $2 / 3$ & 3 \\
\hline New Hampshire & 4 & 4 & $4 / 3$ & $3 / 2$ & 2 & $2 / 1$ & 1 & $1 / 2$ & 2 & $2 / 3$ & $3 / 4$ & 4 \\
\hline New Jersey & 3 & 3 & $3 / 2$ & 2 & $2 / 1$ & 1 & 1 & 1 & $1 / 2$ & 2 & $2 / 3$ & 3 \\
\hline New Mexico - North of $34^{\circ}$ latitude & 4 & $4 / 3$ & 3 & $3 / 2$ & 2 & $2 / 1$ & 1 & 1 & $1 / 2$ & $2 / 3$ & 3 & $3 / 4$ \\
\hline South of $34^{\circ}$ latitude & 3 & 3 & $3 / 2$ & $2 / 1$ & 1 & 1 & 1 & 1 & 1 & $1 / 2$ & $2 / 3$ & 3 \\
\hline New York - North of $42^{\circ}$ latitude & 4 & 4 & 4 & $4 / 2$ & 2 & $2 / 1$ & 1 & $1 / 2$ & 2 & $2 / 3$ & $3 / 4$ & 4 \\
\hline South of $42^{\circ}$ latitude & 4 & 4 & $4 / 3$ & $3 / 2$ & $2 / 1$ & 1 & 1 & 1 & $1 / 2$ & 2 & $2 / 3$ & $3 / 4$ \\
\hline North Carolina & 3 & 3 & $3 / 2$ & 2 & $2 / 1$ & 1 & 1 & 1 & $1 / 2$ & $2 / 3$ & 3 & 3 \\
\hline North Dakota & 4 & 4 & 4 & $4 / 3$ & $3 / 2$ & $2 / 1$ & 1 & $1 / 2$ & 2 & $2 / 4$ & 4 & 4 \\
\hline Ohio & 4 & 4 & $4 / 3$ & $3 / 2$ & $2 / 1$ & 1 & 1 & 1 & $1 / 2$ & $2 / 3$ & $3 / 4$ & 4 \\
\hline Oklahoma & 3 & 3 & 3 & $3 / 2$ & $2 / 1$ & 1 & 1 & 1 & $1 / 2$ & 2 & $2 / 3$ & 3 \\
\hline Oregon - East of $122^{\circ}$ longitude & 4 & $4 / 3$ & 3 & $3 / 2$ & 2 & 2 & $2 / 1$ & $1 / 2$ & 2 & $2 / 3$ & 3 & $3 / 4$ \\
\hline West of $122^{\circ}$ longitude & 3 & $3 / 2$ & 2 & 2 & 2 & $2 / 1$ & 1 & 1 & $1 / 2$ & 2 & 2 & $2 / 3$ \\
\hline Pennsylvania - North of $41^{\circ}$ latitude & 4 & 4 & 3 & $4 / 2$ & 2 & $2 / 1$ & 1 & $1 / 2$ & 2 & $2 / 3$ & $3 / 4$ & 4 \\
\hline South of $41^{\circ}$ latitude & 4 & 4 & $4 / 3$ & $3 / 2$ & 2 & $2 / 1$ & 1 & 1 & $1 / 2$ & 2 & $2 / 3$ & $3 / 4$ \\
\hline Rhode Island & 3 & 3 & 3 & $3 / 2$ & $2 / 1$ & 1 & 1 & 1 & $1 / 2$ & 2 & $2 / 3$ & 3 \\
\hline South Carolina & 2 & 2 & 2 & $2 / 1$ & 1 & 1 & 1 & 1 & 1 & $1 / 2$ & 2 & 2 \\
\hline South Dakota & 4 & 4 & 4 & $4 / 2$ & 2 & $2 / 1$ & 1 & $1 / 2$ & 2 & $2 / 3$ & $3 / 4$ & 4 \\
\hline Tennessee & 3 & 3 & $3 / 2$ & 2 & $2 / 1$ & 1 & 1 & 1 & $1 / 2$ & 2 & $2 / 3$ & 3 \\
\hline Texas - North of $31^{\circ}$ latitude & 3 & 3 & $3 / 2$ & 2 & $2 / 1$ & 1 & 1 & 1 & $1 / 2$ & 2 & $2 / 3$ & 3 \\
\hline South of $31^{\circ}$ latitude & 2 & 2 & 2 & $2 / 1$ & 1 & 1 & 1 & 1 & 1 & $1 / 2$ & 2 & 2 \\
\hline Utah & 4 & $4 / 3$ & 3 & $3 / 2$ & 2 & $2 / 1$ & 1 & 1 & $1 / 2$ & $2 / 3$ & 3 & $3 / 4$ \\
\hline Vermont & 4 & 4 & $4 / 3$ & $3 / 2$ & 2 & $2 / 1$ & 1 & $1 / 2$ & 2 & $2 / 3$ & $3 / 4$ & 4 \\
\hline Virginia & 3 & 3 & $3 / 2$ & 2 & $2 / 1$ & 1 & 1 & 1 & $1 / 2$ & 2 & $2 / 3$ & 3 \\
\hline Washington - East of $122^{\circ}$ longitude & 4 & $4 / 3$ & $3 / 2$ & 2 & 2 & $2 / 1$ & 1 & 1 & $1 / 2$ & $2 / 3$ & 3 & $3 / 4$ \\
\hline West of $122^{\circ}$ longitude & 3 & $3 / 2$ & 2 & 2 & 2 & $2 / 1$ & 1 & 1 & $1 / 2$ & 2 & 2 & $2 / 3$ \\
\hline West Virginia & 4 & $4 / 3$ & 3 & $3 / 2$ & 2 & $2 / 1$ & 1 & $1 / 2$ & 2 & $2 / 3$ & 3 & $3 / 4$ \\
\hline Wisconsin & 4 & 4 & 4 & $4 / 2$ & 2 & $2 / 1$ & 1 & $1 / 2$ & 2 & $2 / 3$ & $3 / 4$ & 4 \\
\hline Wyoming & 4 & 4 & 4 & $4 / 3$ & $3 / 2$ & 2 & $2 / 1$ & $1 / 2$ & 2 & $2 / 4$ & 4 & 4 \\
\hline
\end{tabular}




\section{Appendix D: UL-Certified E25 and E85 Fuel Dispensing Equipment List}

\begin{tabular}{|c|c|c|}
\hline Manufacturer & Equipment & Model \\
\hline Gilbarco & Dispenser & $\begin{array}{l}\text { Encore Series } 300,500,550,700 \text {, may be suffixed S, Model } N \text { fol- } \\
\text { lowed by A, followed by } 0,1,2 \text {, or } 3\end{array}$ \\
\hline Gilbarco & Dispenser & $\begin{array}{l}\text { Encore Series } 300,500,550,700 \text {, may be suffixed S, Model } N \text { fol- } \\
\text { lowed by B, followed by } 0,1,2,3 \text {, or } 4\end{array}$ \\
\hline Gilbarco & Dispenser & Encore Series 300, Model N followed by G, followed by 0 or 1 \\
\hline Gilbarco & Dispenser & $\begin{array}{l}\text { Encore Series } 300,500,550,700 \text {, may be suffixed } S \text {, Model } N \text { fol- } \\
\text { lowed by } F \text { followed by } 0,1 \text {, or } 2\end{array}$ \\
\hline Gilbarco & Dispenser & $\begin{array}{l}\text { Encore Series } 500,550,700 \text {, may be suffixed S, Model } N \text { followed } \\
\text { by } \mathrm{G} \text {, followed by } 0 \text { or } 1\end{array}$ \\
\hline Gilbarco & Dispenser & $\begin{array}{l}\text { Encore Series } 300,500,550,700 \text {, may be suffixed S, Model } \mathrm{N} \text { fol- } \\
\text { lowed by J, followed by } 0,2 \text {, or } 4\end{array}$ \\
\hline Gilbarco & Dispenser & $\begin{array}{l}\text { Encore Series } 300 \text {, may be suffixed } S \text {, Model } N \text { followed by } L \text { or } N \text {, } \\
\text { followed by } 0,1,2 \text {, or } 3\end{array}$ \\
\hline Gilbarco & Dispenser & $\begin{array}{l}\text { Encore Series } 500,550,700 \text {, Model } N \text { followed by } L \text { or } N \text {, followed } \\
\text { by } 0,1,2 \text {, or } 3\end{array}$ \\
\hline Gilbarco & Dispenser & $\begin{array}{l}\text { Encore Series 300, may be suffixed S, Model N followed by P3, P4, } \\
\text { or P5 }\end{array}$ \\
\hline Gilbarco & Dispenser & Encore Series 500, 550, 700, Model N followed by P3, P4, P5, P6, P8 \\
\hline Gilbarco & $\begin{array}{l}\text { Dispenser } \\
\text { (Blender Pump) }\end{array}$ & $\begin{array}{l}\text { Encore } 700 \text { S NA0, NA1, NA2, NA3, NG0, NG1, NN1, NN2, NN3, NLO, } \\
\text { NL1, NL2, NL3, NJ2, NJ4 }\end{array}$ \\
\hline Wayne & Dispenser & $\begin{array}{l}\text { Model G610 with prefix E/, followed by } 1 \text {, followed by D, with or } \\
\text { without one or more of the suffixes } 7 A, 7 B, 8, J, K \text { or Z, with or } \\
\text { without one or more of the suffixes J, W1, S, S1, or S2, for use } \\
\text { with E85. }\end{array}$ \\
\hline Wayne & Dispenser & $\begin{array}{l}\text { Model G620 or G520, with prefix E, followed by } 1,2 \text { or } 3 \text {, followed by } \\
D \text {, with or without one or more of the suffixes } 2,5,7 A, 7 B, 8, G, J, K \text {, } \\
\text { M, or Z, with or without one or more of the suffixes A, B, C, F, H, J, } \\
\text { M1, or W1, for use with E85. }\end{array}$ \\
\hline Wayne & Dispenser & $\begin{array}{l}\text { Ovation Series, Model E, followed by B or R, followed by } 1 \text { or } 2 \text {, } \\
\text { followed by } 1,2 \text { or } 3 \text {, followed by } 1,2,3,4 \text { or } 5 \text {, followed by } 1 \text { or } 2 \text {, } \\
\text { followed by } 1 \text { or } 2 \text {, followed by } 0 \text {, followed by } D \text {, followed by } 0,1,2 \text {, } \\
\text { or } 3 \text {, may be followed by one or more of the option codes } C, D, E, H \text {, } \\
\text { I, J, K, L, M, N, P, S, T, X, 6, or 7, for use with E85. }\end{array}$ \\
\hline Wayne & Dispenser & $\begin{array}{l}\text { Model E followed by 3/G2 or 3/G7, followed by } 2 \text {, followed by } 0 \text {, fol- } \\
\text { lowed by } 1,2,3,7 \text { or } 8 \text {, followed by } D \text {, with or without one or more } \\
\text { suffixes } 1,2,8, G, H, J, K, P 1, R, S, S 1 \text {, S2, or S3, followed by one or } \\
\text { more suffixes } E, H, I, I 2, J, K, L \text {, or } X \text {, for use with E85 }\end{array}$ \\
\hline
\end{tabular}

Table D1 continued on next page. 


\section{Appendix D: UL-Certified E25 and E85 Fuel Dispensing Equipment List}

\begin{tabular}{|c|c|c|}
\hline Manufacturer & Equipment & Model \\
\hline Wayne & $\begin{array}{l}\text { Dispenser (UL } \\
\text { listing up to E25) }\end{array}$ & $\begin{array}{l}\text { Helix Series, Models } \mathrm{H} \text {, followed by } \mathrm{N} \text { or } \mathrm{W} \text {, followed by LM or LU, } \\
\text { followed by } 1,2,3 \text {, or } 4 \text {, followed by } 1,2,3,4 \text {, or } 5 \text {, followed by } 1,2,3 \text {, } \\
\text { or } 4 \text {, followed by } 1 \text { or } 2 \text {, followed by } \mathrm{P} \text { and/or } \mathrm{R}, \mathrm{V} \text {. }\end{array}$ \\
\hline Gasboy & Dispenser & Atlas E85 9872KX \\
\hline OPW & Breakaway & OPW66V-0492 (UL listed E0-E85); 66V-0300 (UL listed E0-E25) \\
\hline OPW & Swivel Connector & $\begin{array}{l}\text { 241TPS-0492 (UL listed EO-E85); 241TPS-0241 (UL listed EO-E25); } \\
\text { 241TPW-1000 (UL listed EO-E25); 241TPW-0492 (UL listed EO-E25) }\end{array}$ \\
\hline OPW & Nozzle & $21 \mathrm{GE}$ \\
\hline OPW & Nozzle & 21GE-A \\
\hline OPW & Shear Valves & 10P-0152E85 \\
\hline OPW & Shear Valves & 10P-4152E85 \\
\hline Veyane & Hose & Flexsteel Futura Ethan-ALL \\
\hline Franklin Fueling & $\begin{array}{l}\text { Submersible } \\
\text { Turbine Pump }\end{array}$ & $\begin{array}{l}\text { Basic Model designation STP with or without } T \text {, with } A G \text {, with or } \\
\text { without } F \text {, with or without } H \text {, with or without } \mathrm{K} \text {, with or without } \mathrm{M} \text {, } \\
\text { with or without R, with or without V, with or without } \mathrm{W} \text {, followed } \\
\text { by } 33,75,150,200 \text {, VS2, or VS4, may be followed by A or B or C, } \\
\text { followed by -XXX (where XXX is numeric characters or VL1, VL2, or } \\
\text { VL3 to indicate model length), and then followed by two characters } \\
\text { (to indicate riser length). All models have been evaluated for use } \\
\text { with gasoline-ethanol blends of } 0 \% \text { to } 85 \% \text { ethanol with gasoline }\end{array}$ \\
\hline Franklin Fueling & $\begin{array}{l}\text { Submersible } \\
\text { Turbine Pump }\end{array}$ & $\begin{array}{l}\text { Basic Model designation IST (with AG is implied) with or without } \\
\text { T, with or without F, with or without } K \text {, with or without M, with or } \\
\text { without R, with or without V, with or without } \mathrm{W} \text {, with or without } \\
\text { VS4 (without indicates VS2 is implied), followed by -XXX (where } \\
\text { XXX is numeric character 1, 2, or } 3 \text { or VL1, VL2, or VL3 to indicate } \\
\text { model length), and then followed by two characters (to indicate } \\
\text { riser length). All models have been evaluated for use with gasoline- } \\
\text { ethanol blends of } 0 \% \text { to } 85 \% \text { ethanol with gasoline }\end{array}$ \\
\hline Red Jacket & $\begin{array}{l}\text { Automatic Tank } \\
\text { Gauge }\end{array}$ & Pro Max FJ PX-2, ProPlus PP2 \\
\hline Red Jacket & $\begin{array}{l}\text { Submersible } \\
\text { Turbine Pumps }\end{array}$ & STP AG07551 FJ2, AGP15021 RJ2, AGP200S1-3 RJ2 \\
\hline Veeder-Root & $\begin{array}{l}\text { Automatic Tank } \\
\text { Gauge }\end{array}$ & ATG/TLS TLS-300C, TLS-350 Plus, TLS-350R \\
\hline Veeder-Root & Tank Probes & $\begin{array}{l}\text { Mag Plus Stainless Steel Probe } 846391-4 x x \text { to } 6 x x \text {, Mag Plus Probe } \\
847390-x x x\end{array}$ \\
\hline Veeder-Root & Sensors & $794380-323,794380-344,794380-345,794380-430$ \\
\hline
\end{tabular}

Table D1 continued on next page. 


\section{Appendix D: UL-Certified E25 and E85 Fuel Dispensing Equipment List}

Table D1 (continued). UL-Certified E25 \& E85 Fuel Dispensing Equipment List

\begin{tabular}{|c|c|c|}
\hline Manufacturer & Equipment & Model \\
\hline RT/Dygert International & Gasket and Seal & N-7079 (Nitrile) for static and dynamic applications \\
\hline RT/Dygert International & Gasket and Seal & F-7036 (Fluorocarbon) for static and dynamic applications \\
\hline RT/Dygert International & Gasket and Seal & FLT-7003 (Fluorocarbon) for static and dynamic applications \\
\hline RT/Dygert International & Gasket and Seal & FS-7002 (Fluorosilicone) for static applications \\
\hline Fusion Inc. & Gasket and Seal & V9701 (Viton A) for dynamic applications \\
\hline Fusion Inc. & Gasket and Seal & V9702 (Viton B) for static and dynamic applications \\
\hline Fusion Inc. & Gasket and Seal & V9703 (Viton GF) for static and dynamic applications \\
\hline Fusion Inc. & Gasket and Seal & V9704 (Viton GFLT) for static and dynamic applications \\
\hline Fusion Inc. & Gasket and Seal & F7010 (Fluorosilicone) for static and dynamic applications \\
\hline $\begin{array}{l}\text { GE Mao Rubber } \\
\text { Industrial Co. }\end{array}$ & Gasket and Seal & $\begin{array}{l}\text { N7060AA (Nitrile Thermoset Rubber) for static and dynamic } \\
\text { applications }\end{array}$ \\
\hline $\begin{array}{l}\text { GE Mao Rubber } \\
\text { Industrial Co. }\end{array}$ & Gasket and Seal & $\begin{array}{l}\text { F7004BU02 (Fluorosilicone) for static and dynamic } \\
\text { applications }\end{array}$ \\
\hline International Seal Co. & Gasket and Seal & V121 (Fluorocarbon) for static and dynamic applications \\
\hline International Seal Co. & Gasket and Seal & V123 (Fluorocarbon) for static and dynamic applications \\
\hline Parco Inc. & Gasket and Seal & 9131-75 (Fluorocarbon) for static and dynamic applications \\
\hline Parco Inc. & Gasket and Seal & 9124-65 (Fluorocarbon) for static and dynamic applications \\
\hline Parco Inc. & Gasket and Seal & 9167-60 (Fluorocarbon) for static and dynamic applications \\
\hline Parco Inc. & Gasket and Seal & 1932-75 (Fluorosilicone) for static applications only \\
\hline Parker Hannifin & Gasket and Seal & V1163-75 (Fluorocarbon) for static and dynamic applications \\
\hline Parker Hannifin: O-ring Div. & Gasket and Seal & N0497-70 (Nitrile) for static and dynamic applications \\
\hline Parker Hannifin: O-ring Div. & Gasket and Seal & N1500-75 (Nitrile) for static and dynamic applications \\
\hline Parker Hannifin: O-ring Div. & Gasket and Seal & L1120-70 (Fluorosilicone) for static and dynamic applications \\
\hline Parker Hannifin: O-ring Div. & Gasket and Seal & V1263-75 (Fluorosilicone) for static and dynamic applications \\
\hline Parker Hannifin: O-ring Div. & Gasket and Seal & V1163-75 (Fluorocarbon) for static and dynamic applications \\
\hline Parker Hannifin: O-ring Div. & Gasket and Seal & V1436-75 (Silicone) for static and dynamic applications \\
\hline Parker Hannifin: Seals Div. & Gasket and Seal & VG273-75 (Fluorocarbon) for static and dynamic applications \\
\hline
\end{tabular}




\section{Appendix E: Procedures for Determining Selected Properties of Ethanol Fuel Samples}

\section{Procedure for Testing Hydrocarbon Percent of Ethanol Fuel Samples Based on SAE International Paper 912421}

\section{Sampling}

E85 is a form of alternative transportation fuel that can be produced from a wide range of renewable feedstocks. As is the case with all fuels, it is critical that the integrity of the fuel be maintained and that seasonal volatility adjustments be made. The following summary describes a "field test" procedure to determine the levels of hydrocarbon and alcohol in E85.

Note: This method is appropriate for field testing only. If you need to test ethanol content for regulatory compliance, refer to D5501 within ASTM D5798.

\section{Equipment for E85 testing}

VWR Scientific phone: $800-932-5000$

$50 \mathrm{~mL}$ pipettes: Cat. \#52966-217

Safety bulb: Cat. \#53497-202

$100 \mathrm{~mL}$ cylinders: Cat. \#24762-117

\section{Procedure}

1. Using the suction bulb, pipette exactly $50 \mathrm{~mL}$ of fuel sample into the graduated cylinder.

2. Add about $48 \mathrm{~mL}$ of water to make the total liquid volume just less than $100 \mathrm{~mL}$.

3. Place the stopper in the cylinder and shake vigorously for about 15 seconds.

4. Carefully loosen the stopper to release any accumulated pressure; do not remove the stopper.

5. Close the stopper again and place the cylinder upright on a level surface. Allow the mixture to sit for about 15 minutes.

6. Record the total volume of liquid by reading the lowest part of the upper meniscus (the curved interface between the liquid and air).

7. Record the total volume of the alcohol/water layer by reading the lowest part of the lower meniscus (the curved interface between the two liquid layers).

\section{Calculation}

1. The hydrocarbon percent is calculated by: $2.1+1.94 *$ (total volume - alcohol/water volume)

2. Assuming the sample was an ethanol/hydrocarbon mixture, the ethanol percent is 100 minus the hydrocarbon percent.

Hydrocarbon and alcohol-resistant gloves are recommended when collecting samples and conducting tests. Testing should be done in a well-ventilated area. Additionally, eye protection should be utilized. Testing personnel should also carry water in plastic containers. 


\section{Appendix E: Procedures for Determining Selected Properties of Ethanol Fuel Samples}

\section{Procedure for Testing Conductivity of Ethanol Fuel Samples Based on ASTM D1125}

\section{Sampling}

Fuel dispensing equipment and sample containers can contaminate the sample, giving a falsely high conductivity for the bulk sample. Dispensing systems should be purged (at least 2 gallons for an aboveground tank and at least 5 gallons for an underground tank) immediately prior to sample collection.

Note: The scope and precision of the following method is not approved for fuels containing ethanol. It has, however, been applied to determine conductivity in these fuels.

\section{Equipment for E85 testing}

VWR Scientific phone: $800-932-5000$

Conductivity meter and gold plated dip cell: Cat. \#23198-013

Dip cell; Cat. \#23198-016

$250 \mathrm{~mL}$ disposable polypropylene beaker: Cat. \#13915-566

\section{Calibration and Setup}

Regularly calibrate the instrument according to manufacturer's specification and enable temperature compensation option.

\section{Procedure}

Note: Fuel samples and the conductivity probe are easily contaminated. Take care not to contaminate the sample or conductivity probe by dirt or even fingerprints. The probe should be kept clean and not laid on a lab or work bench.

1. Add about $200 \mathrm{~mL}$ of fuel to beaker.

2. Insert the conductivity probe into the sample; move the probe up and down to flush out the electrodes. Discard the sample and add a second $200 \mathrm{~mL}$ sample into the beaker.

3. Repeat step 2.

4. Wait for about 30 seconds for the reading to stabilize, then record conductivity in $\mathrm{uS} / \mathrm{cm}$. Multiply number by 100 to give the units of $\mathrm{uS} / \mathrm{m}$. 


\section{Appendix F: Benefits and Limitations of E85}

\section{Benefits}

Energy security: About three-quarters of U.S. petroleum demand is in the transportation sector. Approximately $45 \%$ of U.S. petroleum is imported. Depending heavily on foreign petroleum supplies puts the United States at risk for trade deficits and supply disruptions. RFA's 2012 Ethanol Industry Outlook calculated that in 2011 the ethanol industry replaced the gasoline produced from more than 485 million barrels of imported oil. E85 can be an effective option to reduce gasoline use: Figure 3 illustrates that, with a petroleum energy ratio of 0.1 , ethanol produced from either corn or cellulose is an effective option for reducing petroleum fuel use.

Contribution to the economy: According to RFA, the ethanol industry contributed $\$ 43.4$ billion to the U.S. gross domestic product and $\$ 30.2$ billion to household income in 2012; the industry directly employed 87,000 U.S. workers.

Positive energy balance: Much less fossil energy is required to produce ethanol than to produce gasoline. Ethanol has a positive energy balance when production is evaluated in terms of fossil energy use. The energy balance (the ratio of energy in the fuel to energy required to produce it) of any fuel, including gasoline, will always be less than one. In evaluating the energy balance of a fuel, the type of energy used for production, as well as the amount of energy used, must be considered. Figure 3 illustrates that the production of ethanol from corn has a positive energy balance: Only $0.74 \mathrm{Btu}$ of fossil energy from petroleum, natural gas, and coal are required to produce $1 \mathrm{Btu}$ of energy contained in ethanol. Although $1.75 \mathrm{Btu}$ of total energy is required, $60 \%$ of that energy comes from sunlight captured through photosynthesis during corn plant growth.

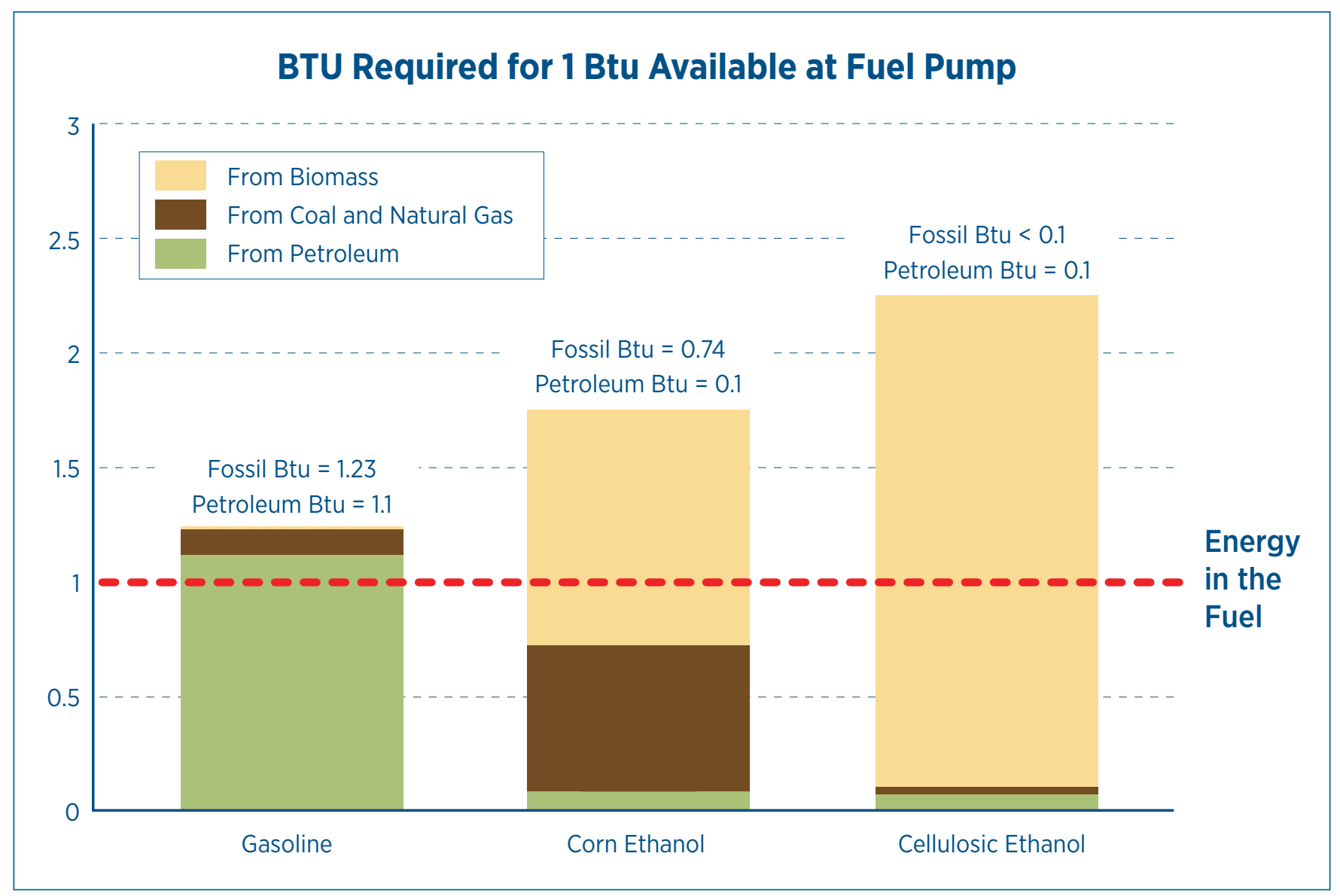

Figure 3. Energy Balance of Gasoline and E85, Argonne National Laboratory Center for Transportation Research. Source: Michael Q. Wang 
Lower greenhouse gas emissions: On a life-cycle basis (including fuel production and distribution), E85 made with corn ethanol reduces carbon dioxide emissions by $19 \%$ relative to gasoline. When ethanol is made from cellulose materials, such as corn and wheat stalks or forestry waste, it can reduce greenhouse gas emissions by $86 \%{ }^{1}$

\section{Emissions reductions of some regulated toxics:}

Exhaust emissions from the combustion of gasoline contain small amounts of regulated toxics, such as benzene and 1,3-butadiene. Use of E85 can substantially reduce emissions of these toxics. Acetaldehyde emissions from the combustion of E85 are higher than those of gasoline, but acetaldehyde is much less toxic than benzene and 1,3-butadiene.

Use of existing fueling infrastructure: Most existing tanks are compatible with E85 (see Appendix A). ULlisted E85 dispensers and hanging hardware, as well as other types of equipment, are available (see Appendix D). Ethanol is currently shipped to distribution terminals via trucks and rail cars. Due to ethanol's affinity for water, only small batches are shipped via existing petroleum fuel pipelines.

\section{Limitations}

Lower fuel economy: A gallon of ethanol contains less energy than a gallon of gasoline, resulting in lower fuel economy. According to EPA estimates, the fuel economy of today's FFVs is $20 \%$ to $30 \%$ lower when running on E85, relative to its fuel economy on gasoline. Reductions in fuel economy are proportional to the percentage of ethanol in the fuel. Use the "Find a Car" tool on FuelEconomy.gov ${ }^{2}$ to view side-by-side fuel economy estimates for E85 and gasoline operation for individual FFV models.

Limited availability: In many locations, E85 and other ethanol blends are much less widely available than gasoline. However, the number of stations has increased dramatically during the last decade. As of April 2013, there were more than 2,300 stations selling E85 in the United States, compared to approximately 156,000 conventional gasoline stations. Federal and state incentives are available to help stimulate E85 fueling infrastructure development. ${ }^{3}$ The successful establishment of several hundred E85 stations in Minnesota's Minneapolis-St. Paul metropolitan area has demonstrated the potential for E85 infrastructure growth in major U.S. cities.

Vehicle modifications: Substantial modifications to conventional vehicles are necessary to provide flexiblefuel capability. Modifications typically consist of fuel system material and component upgrades, as well as additional software, engine calibration, and engineering to meet emission, fuel economy, and performance requirements.

Misfueling: As E15 and E85 become more widely available, with attractive retail pricing, the risk of misfueling increases. E15 is not approved for use in conventional vehicles older than model year 2001. Only FFVs can use ethanol blends higher than E15. EPA has issued a misfueling mitigation rule to address potential E15 misfueling in the marketplace. Misfueling may result in some short- and long-term vehicle fuel system component failures and driveability complaints. The risk of misfueling reinforces the need for prominent signage at fueling stations.

\footnotetext{
1. Wang, M., Wu, M., Huo, H. "Life-cycle energy and greenhouse gas emission impacts of different corn ethanol plant types." Argonne National Laboratory. April 27, 2007.

2. www.fueleconomy.gov/feg/alternatives.shtml

3. afdc.energy.gov/laws
} 


U.S. DEPARTMENT OF ENERCY

Energy Efficiency \& Renewable Energy

Clean Cities Technical Response Service 800-254-6735

technicalresponse@icfi.com

To view this and other Clean Cities publications online, visit cleancities.energy.gov/publications.

Prepared by the National Renewable Energy Laboratory (NREL), a national laboratory of the U.S. Department of Energy, Office of Energy Efficiency and Renewable Energy; operated by the Alliance for Sustainable Energy, LLC.

DOE/GO-102013-3861 • September 2013

Printed with a renewable-source ink on paper containing at least $50 \%$ wastepaper, including $10 \%$ post consumer waste. 